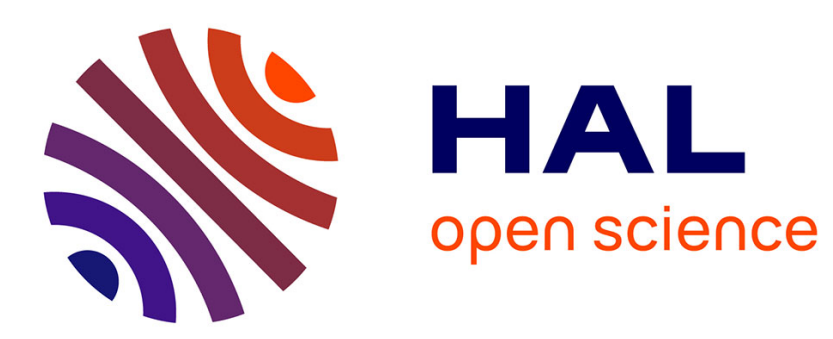

\title{
The paradox of the construction [V zai NPloc] and its meanings in the Beijing dialect of Mandarin
}

Katia Chirkova, Christine Lamarre

\section{To cite this version:}

Katia Chirkova, Christine Lamarre. The paradox of the construction [V zai NPloc] and its meanings in the Beijing dialect of Mandarin. Cahiers de linguistique - Asie Orientale, 2005, 34 (2), pp.169 220. 10.3406/clao.2005.1735 . hal-01381969

\section{HAL Id: hal-01381969 \\ https://hal-inalco.archives-ouvertes.fr/hal-01381969}

Submitted on 14 Oct 2016

HAL is a multi-disciplinary open access archive for the deposit and dissemination of scientific research documents, whether they are published or not. The documents may come from teaching and research institutions in France or abroad, or from public or private research centers.
L'archive ouverte pluridisciplinaire HAL, est destinée au dépôt et à la diffusion de documents scientifiques de niveau recherche, publiés ou non, émanant des établissements d'enseignement et de recherche français ou étrangers, des laboratoires publics ou privés. 


\title{
The paradox of the construction [V zai NPloc] and its meanings in the Beijing dialect of Mandarin
}

\author{
Katia Chirkova, Christine Lamarre
}

\section{Résumé}

Cet article traite de l'interprétation en pékinois des constructions locatives du type 'V zai NPloc' où le syntagme locatif suit le verbe. Nous montrons, à partir d'un corpus de langue parlée recueilli à Pékin en 2000-2001, qu'à l'inverse du chinois standard, où ces constructions ont deux interprétations possibles - durative et terminative pour les verbes de posture et de placement, en pékinois seule l'interprétation terminative de déplacement est retenue (comme dans le pékinois de la fin des Qing et les dialectes du nord). Nous proposons aussi une explication aux exceptions observées.

\begin{abstract}
This article focuses on the meanings of the postverbal locative construction in the Beijing dialect of Mandarin, as attested in a spoken corpus collected in 2000-2001. We show that in contrast to Standard Mandarin, where this construction has been argued to have two meanings (durative and terminative) for verbs of posture and placement, on the one hand, and in uniformity with Beijing Mandarin texts of the late Qïng and with Northern Mandarin data, on the other, this construction in the Beijing dialect of Mandarin has only one, terminative, meaning for all verbs. We also propose an explanation for the existing exceptions to this pattern.
\end{abstract}

\section{Citer ce document / Cite this document :}

Chirkova Katia, Lamarre Christine. The paradox of the construction [V zai NPloc] and its meanings in the Beijing dialect of Mandarin. In: Cahiers de linguistique - Asie orientale, vol. 34 2, 2005. pp. 169-220;

doi : 10.3406/clao.2005.1735

http://www.persee.fr/doc/clao_0153-3320_2005_num_34_2_1735

Document généré le 02/06/2016 


\title{
The paradox of the construction [ $\left.\mathrm{V} z a i \mathrm{NP}_{\mathrm{Loc}}\right]$ and its meanings in the Beijing dialect of Mandarin'
}

\author{
Katia CHIRKOVA \& Christine LAMARRE
}

This article focuses on the meanings of the postverbal locative construction in the Beijing dialect of Mandarin, as attested in a spoken corpus collected in 2000-2001. We show that in contrast to Standard Mandarin, where this construction has been argued to have two meanings (durative and terminative) for verbs of posture and placement, on the one hand, and in uniformity with Beijing Mandarin texts of the late Qing and with Northern Mandarin data, on the other, this construction in the Beijing dialect of Mandarin has only one, terminative, meaning for all verbs. We also propose an explanation for the existing exceptions to this pattern.

Key words : postverbal locative construction, terminative, durative, the Beijing dialect of Mandarin, Northern Mandarin, vernacular Qing texts.

Cet article traite de l'interprétation en pékinois des constructions locatives du type ' $\mathrm{V}$ zai $\mathrm{NP}_{\text {Loc }}$ ' où le syntagme locatif suit le verbe. Nous montrons, à partir d'un corpus de langue parlée recueilli à Pékin en 2000-2001, qu'à l'inverse du chinois standard, où ces constructions ont deux interprétations possibles -- durative et terminative -- pour les verbes de posture et de placement, en pékinois seule l'interprétation terminative de déplacement est retenue (comme dans le pékinois de la fin des Qing et les dialectes du nord). Nous proposons aussi une explication aux exceptions observées.

Mots-clés : constructions à syntagme locatif postverbal, terminatif, duratif, pékinois, dialectes de la Chine du nord, textes vernaculaires des Qīng.

\footnotetext{
' We are grateful to Jeroen Wiedenhof for useful comments on an earlier version of this article, and also to the anonymous reviewers of the CLAO for helpful criticism on a second draft.
}

Cahiers de Linguistique - Asie Orientale 34(2): 169-220 (2005)

(C) CRLAO-EHESS 54, Bd Raspail 75006 Paris

0153-3320/2005/034-169 
Chirkova K. \& Lamarre C. / Cahiers de Linguistique - Asie Orientale 34(2005) 169-220

1. THE PARADOX OF THE CONSTRUCTION [V ZAI NP ${ }_{\text {LOC }}$ ], EARLY QING SOURCES AND SIMILAR PATTERNS IN NORTHERN MANDARIN DIALECTS

\subsection{The paradox of the construction [V zai $\mathrm{NP}_{\mathrm{LOC}}$ ]}

In the syntactic system of Standard Mandarin, verb phrases followed by a locative phrase introduced by the coverb 在 zai 'be in' (hereafter the [ $\left.\mathrm{V} z a i \mathrm{NP}_{\mathrm{Loc}}\right]$ construction) function as a terminative construction that denotes a change of location. ${ }^{2}$ The terminative meaning of the [ $\left.\mathrm{V} z a i \mathrm{NP}_{\mathrm{Loc}}\right]$ construction is illustrated in examples (1) and (2), quoted from Peyraube (1980: 233) and Xú (1994a: 342) (our glosses) respectively. ${ }^{3}$

\footnotetext{
${ }^{2}$ Hereafter we will refer to 在 zài zai and 到 dào dao as coverbs. A coverb introduces a noun phrase; the phrase formed by a coverb and the following (locative) noun phrase can both precede and follow the main verb (cf. Li and Thompson 1981: 356). Hereafter the form zai stands for postverbal uses of 在, whereas zài for preverbal uses. In a similar fashion, dao stands for postverbal uses of 到, whereas dào - for preverbal.

In this article, we will use the term terminative in a sense similar to Nedjalkov and Jaxontov (1988: 5), i.e. "denot[ing] a transition from one state into another" and as opposed to durative, in our formulation, a process or state seen as continuing for an appreciable time, cf. Verkuyl (1993: 3-16). This opposition between terminative (a change of location) and durative (a state resulting from a change of location) roughly corresponds to that between bounded and unbounded or that between punctual and durative in Comrie's terminology (1976). We deliberately avoid the term resultative construction throughout the discussion, given that different authors variously understand it as referring to constructions "express[ing] a state implying a previous event" (Nedjalkov and Jaxontov 1988: 6), i.e. close to our understanding of durative, or as being essentially terminative (Verkuyl 1993: 30 and 1993: 329-32, see also a discussion in Goldberg and Jackendoff 2004).

${ }^{3}$ Unless otherwise specified, all examples in this article are quoted from a corpus of spoken Beijing Mandarin collected by Chirkova in 2000-2001 (hereafter corpus). Following Yuen Ren Chao (1968: xvii), we give examples both in characters and in romanized transcriptions (Hànyŭ Pīnyīn, in our case), with an English gloss. The characters are included for the convenience of readers who feel more comfortable with them than with romanization. For more details on the corpus, see $\S 1.5$.
} 
The paradox of the construction $\left[\mathrm{V}\right.$ zai $\left.\mathrm{NP}_{\mathrm{LOC}}\right] \ldots$ / CLAO 34(2005) 169-220

(1)

真 了不得, 他 掉 在 水 里 了$^{4}$ 。
Zhēn liăobudé tā diào zai shuí li le.
really terrible he fall be.in water inside CRS
'Good God! He fell into the water!'

(2)

$\begin{array}{lllll}\text { 把 手 } & \text { 放 } & \text { 在 } & \text { 背 } & \text { 后! } \\ \text { Bá shǒu fàng zai } & \text { bèi } & \text { hòu! } \\ \text { PTR hand put be.in back } & \text { behind } \\ \text { 'Put your hands behind your back!' } & \end{array}$

In being terminative the [ $\mathrm{V} z a i \mathrm{NP}_{\text {Loc }}$ ] construction is similar to constructions with the postverbal locative phrase introduced by 到 dao 'arrive' (hereafter the [V dao $\mathrm{NP}_{\mathrm{Loc}}$ ] construction).

Paradoxically, the same, essentially terminative, [V zai $\left.\mathrm{NP}_{\mathrm{Loc}}\right]$ construction in Standard Mandarin can also have the durative meaning. This inconsistency has been to our knowledge first noted by Jaxontov (1957: 97, 135; Chinese edition 1958: 100, 140). He points out that the [V zai $\mathrm{NP}_{\mathrm{Loc}}$ ] construction is at variance with the parallel - and always terminative - constructions [V gěi 'give' NP] and [V dao 'arrive' $\left.\mathrm{NP}_{\text {Loc }}\right]$. Conversely, Jaxontov notes that the [ $\mathrm{V}$ zai $\left.\mathrm{NP}_{\mathrm{Loc}}\right]$ construction is different from the [V gěi 'give' NP] and [V dao $\mathrm{NP}_{\text {Loc }}$ constructions in that it can express both a terminative and durative event, depending on the context. He quotes the following examples from Zhōu Libō's 周 立波 novel Bàofêng zhòuyŭ 暴风骤雨 [The tempest]:

\footnotetext{
${ }^{4}$ Abbreviations: 1, 2, 3: first, second, third person personal pronouns; CRS: currently relevant state expressed by the perfective particle le; DUR: durative aspect expressed by the particle zhe; EXP: experiential aspect expressed by the particle guo; HON: honorific form; IGV: interrogative meaning as expressed by the particle ma; L: locative phrase; $\mathrm{N}$ : nominal phrase; $\mathrm{P}$ : plural; RL: particle ne, indicating contextual relevance of the preceding expression; PTR: pre-transitive particle bă băi used to mark a direct object; S: singular; SUB: subordination expressed by the particle de; SUG: suggestion expressed by the particle $b a ; \mathrm{V}$ : verbal phrase. Tone sandhi is indicated in the examples. ${ }^{s}$ Given that the kind of semantic opposition discussed here is better understood from the context, we have consulted the original text of Zhou's novel (1952; we did not have access to the first 1949 edition of the novel used by Jaxontov) and quoted in each case the full sentence, even if Jaxontov quotes only the clause with the locative phrase.
} 
Chirkova K. \& Lamarre C. / Cahiers de Linguistique - Asie Orientale 34(2005) 169-220

白玉山 把 小豆油灯 搁 在

Bái Yùshān bá xiăo dòuyóudēng gē zai Bái Yùshān PTR small bean.oil.lamp put be.in

炕桌上, 拿出本子 和 钢笔, kàngzhuō shang, ná chu běnzi hé gāngbì kàng.table up take exit notebook and steel.pen 在写什么。 zài xiě shénme.

be.in write something

'Bái Yùshān had put the small oil lamp on the kang table, taken out a notebook and a pen, and was now writing something.' (Zhōu 1952: 183, Jaxontov 1957: 135, our glosses)

(4)

$\begin{array}{lllllll}\text { 领 } & \text { 回 } & \text { 来 } & \text { 的 } & \text { 猪肉 } & \text { 还 } & \text { 搁 } \\ \text { Ling } & \text { huí } & \text { lai } & \text { de } & \text { zhūròu hái } & \text { gē } \\ \text { receive } & \text { return } & \text { come } & \text { SUB } & \text { pork } & \text { still } & \text { put } \\ \text { 桌子 } & \text { 上, } & \text { 没 } & \text { 有 } & \text { 者 } & \text { 熟, } & \text { 也 } \\ \text { zhuōzi } & \text { shang, méi } & \text { yóu } & \text { zhŭ } & \text { shóu, yě } \\ \text { table up } & \text { not.exist exist } & \text { boil } & \text { cooked also } \\ \text { 没 } & \text { 有 } & \text { 槑 } & \text { 馅。 } & & \\ \text { méi } & \text { yǒu } & \text { duò } & \text { xiàn. } & & \\ \text { not.exist exist } & \text { chop } & \text { filling } & & \end{array}$

'The pork received from the farmer's union was still lying on the table, she had not cooked or minced it.'

(Zhōu 1952: 182, Jaxontov 1957: 135, our glosses)

To sum up, the essence of the [ $\mathrm{V} z a i \mathrm{NP}_{\text {Loc }}$ ] construction paradox is as follows: despite the overall tendency in Mandarin for the postverbal constructions with dao 'arrive' and gěi 'give' to express the terminative meaning, the $\left[\mathrm{V} z a i \mathrm{NP}_{\mathrm{Loc}}\right]$ construction can express both the terminative and the durative meaning. 
The paradox of the construction [V zai $\left.\mathrm{NP}_{\mathrm{Loc}}\right]$... / CLAO 34(2005) 169-220

1.2. Previous studies on the construction [V zai $\mathrm{NP}_{\mathrm{Loc}}$ ]

Previous studies on the $\left[\begin{array}{lll}\mathrm{V} & z a i & \mathrm{NP}_{\mathrm{Loc}}\end{array}\right]$ construction concentrate mainly on the following two issues.

First, the research focus has been placed on the semantic correlate of the position of the locative phrase, i.e. preverbal or postverbal. The difference, as formulated by James H-Y. Tai (1975: 175), is as follows: "[W]hile the function of a Chinese preverbal place adverbial is to denote the location of an action or a state of affairs, that of a postverbal one is to denote the location of a participant of an action as a result of the action." This interpretation of the postverbal locative phrase as expressing a resultative location adequately accounts for sentences such as example (1). For instance, the meaning 'fall into the water' cannot be expressed by placing the locative phrase preverbally (Peyraube 1980: 233). However, Tai's explanation fails to account for the fact that the meaning of the [ $\mathrm{V} z a i \mathrm{NP}_{\mathrm{Loc}}$ ] and the [zài $\mathrm{NP}_{\text {Loc }} \mathrm{V}$ ] constructions is often considered synonymous and as encoding a durative state, for some verbs of posture and of placement. By verbs of posture we understand verbs that denote the posture or the physical disposition of an entity at a location (cf. Li and Thompson 1981: 219), e.g. zuò 'sit', zhàn 'stand', tăng 'lie'. Verbs of placement are verbs that "name actions that place the direct object in a certain location" (ibid., p. 404), e.g. fang 'put', zhuāng 'install', guà 'hang', suó 'lock'. For the latter category, the sentence has the durative meaning when the patient of the placement verb is topicalized, e.g. in (4). Notably, example (4) is also semantically passive (Wáng 1957 ).

Compare sentences (5) and (6), quoted from Peyraube (1980: 241, our glosses):

$\begin{array}{llllll}\text { 他 } & \text { 在 } & \text { 床 上 } & \text { 躺 } & \text { 着。 } \\ \text { Tāa } & \text { zài } & \text { chuáng shang } & \text { tăng } & \text { zhe. } \\ 3 & \text { be.in } & \text { bed up } & \text { lie } & \text { DUR }\end{array}$

'He is lying on the bed.' 
Chirkova K. \& Lamarre C. / Cahiers de Linguistique - Asie Orientale 34(2005) 169-220

(6)

他 躺 在 床 上。
Tà tăng zai chuáng shang.
3 lie be.in bed up
'He is lying on the bed.'

In Standard Mandarin, the [V zai $\mathrm{NP}_{\mathrm{Loc}}$ ] construction is generally considered to have both the durative and the terminative meaning with the verb $z h \grave{u}$ 'live' and verbs of posture (cf. Wáng 1957, Jaxontov 1988, Tai 1975, Peyraube 1980: 228-260, $\mathrm{Li}$ and Thompson 1981: 397-409), as well as to some extent with verbs of placement (Fàn 1982, Zhū 1982: 182-184, Chén 1988, Zhào 1995).

Fàn (1982: 82-84) demonstrates that the semantic ambivalence of [ $\left.\mathrm{V} z a i \mathrm{NP}_{\mathrm{Loc}}\right]$ sentences is due to the inherent aspectual features of verbs of posture and of placement. ${ }^{6}$ These verbs can be used in the [ $\left.\mathrm{V} z a i \mathrm{NP}_{\mathrm{Loc}}\right]$ construction to denote either a change of location (terminative), as in example (7), or the state that follows the completion of such an event (durative), as in example (8). Both examples are quoted from Fàn (ibid.):

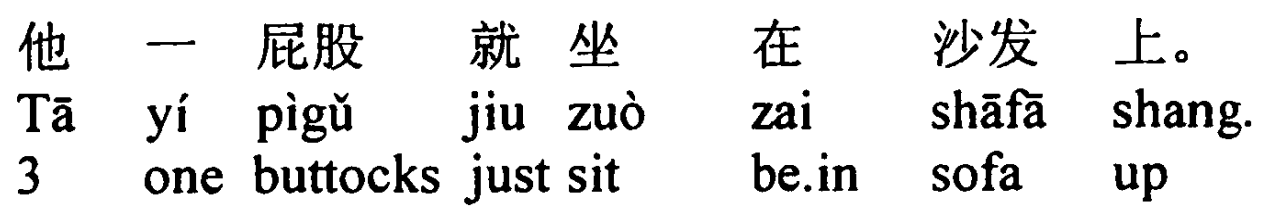

'He flopped onto the sofa.', or

'He sat down with all his weight on the sofa.' (change of location)

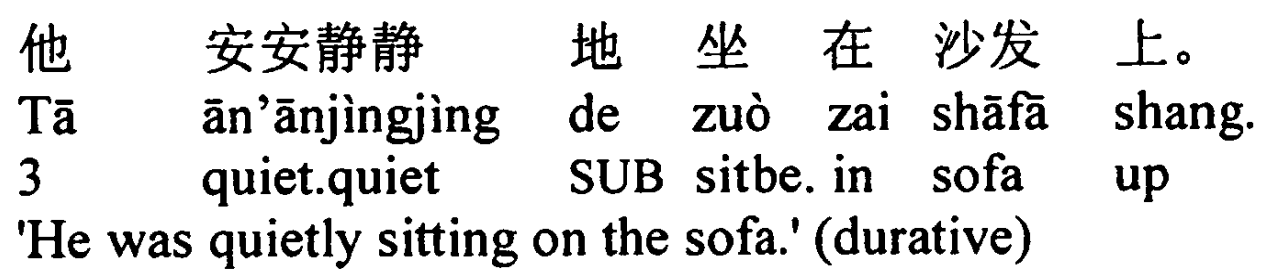

\footnotetext{
${ }^{6}$ For the analysis of the aspectual features of these verbs, see Chen Píng (1988: 408). Chen also comments on the ambiguity of the [V zai $\mathrm{NP}_{\mathrm{Loc}}$ ] construction for this particular set of verbs. Our own more detailed account of verbs of posture follows in $\S 2.2$.
} 
The paradox of the construction [V zai $\left.\mathrm{NP}_{\mathrm{Loc}}\right]$... / CLAO 34(2005) 169-220

The second emphasis in works on constructions with postverbal locative phrases is placed on various means to introduce postverbal locative phrases, i.e. $z a i$ 在 'be in', dao 到 'arrive', the form de 的, and zhe or zhuo 着 (Guō 1986; Jiāng 1994; Xú 1994a, 1994b; Zhào 1995; Yuán 2002). Arguably, the most disputed of these forms is form de used in the Beijing dialect of Mandarin. This form is sometimes considered a blend of the written forms 在 zài and 到 dào in the spoken language (cf. Chao 1968: 353-354, 106-107, Dragunov 1958: 71-72, Zhū 1961: 1, 1982: 182, Guō 1986: 20) or alternatively, as a neutralization of the coverb dao (Xú 1994b: 183). In addition to these forms, studies dealing mainly with synchronic data, e.g. Peyraube (1980: 134-147), Guõ (1986) and Xú (1994a, 1994b), comment on the so-called "zero form" - the term also accepted in this discussion - i.e. the absence of any marker between the verb and the following verb phrase. For instance, Xú (1994a) notes that in the sentence Bá shóu fâng zai bèi hòu! 'Put your hands behind your back!' (example 2), zai 'be in' can be replaced by dao 'arrive', the form de or the zero form, without any change of meaning.

Based on the terminative or durative readings of sentences with various forms introducing postverbal locative phrases as well as on diachronic data, Jiāng (1994) and Yuán (2000) argue that the form de originates from the verb zhuó 着 'attach' and from the verb $d e ́$ 得 'obtain'.

Both issues, i.e. semantic implications of the positioning of the locative phrase and the distribution and meaning of various forms introducing postverbal locative phrases, will be addressed presently.

1.3. Meaning of [ $\left.\mathrm{V} z a i \mathrm{NP}_{\mathrm{Loc}}\right]$ in vernacular texts of the late Qing

As shown by Lamarre (2003a), sentences with the [V zai $\left.\mathrm{NP}_{L o c}\right]$ or the [V de $\left.\mathrm{NP}_{\mathrm{Loc}}\right]$ construction in three texts reflecting the Beijing dialect of Mandarin spoken in the late Qing dynasty (late 
Chirkova K. \& Lamarre C. / Cahiers de Linguistique - Asie Orientale 34(2005) 169-220

19th - beginning of the 20th century) denote exclusively a change of location, i.e. are terminative. For instance, in Guānhuà zhĭnán 官 话指南 [A guide to the Mandarin language] (1881), a textbook compiled by Wú Qìtài and Zhèng Yŏngbāng, Japanese interpreters of Chinese descent, all 39 sentences with the postverbal locative phrase introduced by $z a i$ 'be in' are terminative. Alternatively, when a verb of posture or placement appears in a sentence with the durative meaning (the total of 31 examples in this text), the locative phrase is placed preverbally and the verb usually takes the durative particle $z h e$. Consider the following two sentences with the verb gé 'put':

(9) 胰子 盒兒 在 臉盆 架子 上 擱着 哪。
Yízi hèr zài liănpén jiàzi shang ge zhe na.
soap box be.in wash.basin stand up put DUR RLV
'The soap box is on the washstand.', literally
'The soap box has been put on the washstand.' (vol. III, ch. 3, 46a)

$\begin{array}{lllllllll}\text { (10) } & \text { 你 } & \text { 把 } & \text { 那 } & \text { 発子 } & \text { 拿 } & \text { 過 } & \text { 來。 } & \text { 把 } \\ & \text { Ní } & \text { bă } & \text { nèi } & \text { dèngzi } & \text { ná } & \text { guo } & \text { lai } & \text { bă } \\ & 2 S & \text { PTR } & \text { that } & \text { stool } & \text { take } & \text { cross } & \text { come } & \text { PTR }\end{array}$

煙盤兒 擱 在 上頭。 yānpár gē zài shàngtou. pipe.tray put be.in up.head 'Bring me that stool and put my opium tray on it.'

(vol. III, ch. 7, 48b)

Two more texts that also reflect the Beijing dialect of Mandarin of the same period, Xiăo É 小额 [Young É] (1908) and Yànjīng fùyŭ 燕京妇语 [Metropolitan conversation for ladies] (1906), share the same feature. In these works, the preverbal locative phrase used with verbs of posture and placement normally has the durative meaning, whereas the postverbal locative phrase is associated with the terminative meaning. In other words, in the Beijing dialect of 
The paradox of the construction $\left[\mathrm{V}\right.$ zai $\left.\mathrm{NP}_{\mathrm{LOC}}\right] \ldots$ / CLAO 34(2005) 169-220

Mandarin of the turn of the 20th century, a postverbal locative phrase construction could only express a change of location. ${ }^{7}$ This exclusively terminative meaning of the postverbal locative phrase construction is thus markedly different from the meaning ascribed to this construction in Standard Mandarin. This discrepancy is of interest, given that Standard Mandarin is according to its canonical definition based on the Beijing dialect of Mandarin and that Standard Mandarin and the Beijing dialect of Mandarin are often even considered to be one and the same language, cf. $\mathrm{Li}$ and Thompson (1981: 1) and Norman (1988: 136-7). ${ }^{8}$

\subsection{Postverbal locative phrase constructions in Northern Mandarin dialects}

As demonstrated by Lamarre (2003c) in her study of the Jìzhōu dialect of Héběi, postverbal locative phrase constructions in this dialect express a change of location exclusively. For example, in this dialect, a sentence with the verb zuo 'sit' followed by the locative phrase chuáng shang 'on the bed' can only be used in situations where the subject is standing and is ordered to sit down on the bed, or in situations where the subject, originally standing, sat down on the bed. In other words, such a sentence can only be used to describe the terminative event of sitting down on the bed. A postverbal locative phrase construction, therefore, cannot be used to describe the durative situation following the event of sitting down, as in example (8).

\footnotetext{
${ }^{7}$ In Guānhuà zhĭnán, postverbal locative phrases are introduced by 在 zai 'be in' and 到 dao 'arrive'. Xiăo $E$ and Yànjīng füyŭ, in addition to zai and dao, also make use of the form de and the zero form.

${ }^{8}$ Standard Mandarin, 普通话 pútönghuà 'common speech', according to the 1955 definition by Quánguó wénzì găigé huìì 全国文字改革会议 (the National Language Reform Meeting) is "the standard language of China that takes the pronunciation of Beijing as its norm of pronunciation, is based on the northern dialects, and has the grammar of exemplary modern vernacular texts as its normative grammar" (Guō 2000: 978).
} 
Chirkova K. \& Lamarre C. / Cahiers de Linguistique - Asie Orientale 34(2005) 169-220

Lamarre (2003a) furthermore notices that in contrast to Northern Mandarin dialects, in many dialects spoken in Central and Southern China, sentences with the postverbal locative phrase can have both the terminative and the durative reading (see Xú and Shào 1998: 5-9 for details on the Shanghai dialect). The situation in such dialects is thus reminiscent of that in Standard Mandarin. Lamarre therefore concludes that the possibility for postverbal locative constructions in Standard Mandarin to have both the terminative and the durative reading, similar to Central and Southern dialects, is the result of the latter influencing the original northern pattern with only one meaning - a change of location for postverbal locative phrases. In other words, the durative meaning of postverbal locative phrases in Standard Mandarin is secondary and triggered by Central and Southern patterns.

To sum up, in Northern dialects and early texts reflecting spoken Beijing Mandarin, postverbal locative phrases are exclusively terminative, whereas in some Central and Southern dialects, postverbal locative phrases can express both the terminative and the durative meaning depending on the context. Standard Mandarin follows the Southern pattern. The meaning of this type of construction in the modern Beijing dialect of Mandarin is the focus of this article.

\subsection{Goals, data and terminology}

The aim of this article is twofold.

First, it investigates the meaning of postverbal locative phrases in the Beijing dialect of Mandarin based on a corpus of spoken Beijing Mandarin, collected by Chirkova in 2000-2001. The corpus consists of informal and unplanned conversations with 42 native speakers of the Beijing dialect of Mandarin of various age groups. Chirkova tried to record language consultants who were not exposed to university education and whose language, as a consequence, retained those features that distinguish it from the official educational model, Standard Mandarin. The majority of 
The paradox of the construction [V zai $\left.\mathrm{NP}_{\mathrm{Loc}}\right]$... / CLAO 34(2005) 169-220

language consultants are school children (younger than 20 years old, henceforth referred to as 'younger speakers') and retired workers and employees (above 50 years of age, henceforth referred to as 'older speakers'). The conversations range in length from 30 minutes to one hour and are transcribed in the Hànyŭ Pīnyīn system of transcription. In its written form, the corpus comprises 17,844 sentences. For further details on the corpus, see Chirkova (2003: 611).

In continuation of Lamarre's (2003a, 2003b) research and based on the corpus, we aim to answer the question whether postverbal locative phrase constructions in the Beijing dialect of Mandarin follow the Standard Mandarin pattern and allow for two, terminative and durative readings, or are rather uniform with the Northern and early Beijing Mandarin type, where only one, terminative, reading for the postverbal locative phrase construction is possible.

Another goal of the present study is to document various forms that serve to introduce postverbal locative phrases in the Beijing dialect of Mandarin and to comment on their distribution.

In previous studies on the $\left[\mathrm{V} z a i \mathrm{NP}_{\mathrm{LoC}}\right]$ construction, the two meanings of this construction have been referred to as dynamic (动态 dòngtài) vs. static (静态 jìngtài), e.g. Chén (1988), Jiāng (1994), Fàn (1982). Alternatively, the meanings of the construction have been described as perfective vs. imperfective (Lamarre 2003a, $2003 b$ ). In this article, we will use the term terminative, i.e. denoting a change of location, for what is elsewhere referred to as dynamic or perfective, and durative, i.e. denoting a state resulting from a change of locative, for static or imperfective.

A hotly debated issue in previous studies is the grammatical status of the forms used to introduce postverbal locative phrases, e.g. zai 'be in', dao 'arrive', and the form de, variously referred to as prepositions, coverbs or verbs, acting as complements of the preceding verb. They have also been treated as highly grammaticalized locative markers affixed to the verb, or as locative markers with some properties of aspectual markers (Zhū 1982, Xú 1994a and 1994b, Liú et al. 2000, Liú 2001). 
Chirkova K. \& Lamarre C. / Cahiers de Linguistique - Asie Orientale 34(2005) 169-220

No unifying term that could account for the diversity of the syntactic behaviour of these forms in the written language as well as in various dialects has yet been proposed and in this discussion we will refer to all different means serving to introduce locative phrases simply as forms. Zài zai 'be in' and dào dao 'arrive' are furthermore also referred to as coverbs (see $\mathrm{n} .2$ for definition).

Overall, we will be speaking about the unity or mismatch between construction position and construction meaning. By construction, we understand a verb and an accompanying locative phrase, i.e. [V zai $\mathrm{NP}_{\mathrm{Loc}}$ ] or [zài $\left.\mathrm{NP}_{\mathrm{Loc}} \mathrm{V}\right]$. The construction position depends on the position of the locative phrase and is either preverbal or postverbal. The construction meaning is either durative or terminative. Based on Lamarre (2003a, 2003c), we presume that in Northern Mandarin, phrases with postverbal locative phrases essentially express a change of location. ${ }^{9}$ A postverbal position is hence associated with the terminative meaning, as is also the case with the [ $\mathrm{V}$ dao $\mathrm{NP}_{\text {Loc }}$ ] and [ $\mathrm{V}$ géi $\mathrm{NP}_{\mathrm{Loc}}$ ] constructions in Standard Mandarin. Consequently, when in the corpus a postverbal locative phrase construction is terminative, we describe it as: "construction position and meaning match." When, on the other hand, a postverbal locative phrase construction is durative, we will describe it as: "construction position and meaning do not match."

\section{CORRELATION BETWEEN CONSTRUCTION POSITION AND MEANING IN THE MODERN BEIJING DIALECT OF MANDARIN}

2.1. Forms introducing locative phrases in the Beijing dialect of Mandarin

In the dialect of Beijing, preverbal locative phrases are usually introduced by dăi dài 'be in', āi ăa i 'be next to', and gên 'on',

\footnotetext{
9 Lamarre's findings about the non-occurrence of the durative reading for postverbal locative constructions in Northern dialects have recently been corroborated by her recent field work on several Guānzhōng and Jin dialects of Shānxī and Shănxī.
} 
The paradox of the construction [V zai $\left.\mathrm{NP}_{\mathrm{LOC}}\right]$... / CLAO 34(2005) 169-220

whereas postverbal locative phrases are introduced by the form de (Hú 1991: 42; Mullie 1932: 73; Xú 1994a, 1994b; Zhū 1987: 328329). The use of dài, gēn and de is exemplified in sentences (11)-(13). $\bar{A} i \sim a ̆ i$ 'be next to' has not been attested in this function in the corpus.

In sentence (11), the language consultant speaks about shoes worn in the past by ice peddlers.

\begin{tabular}{|c|c|c|c|c|c|c|}
\hline $\begin{array}{l}\text { 他 } \text { 这 } \\
\text { Tâa zhè } \\
3 \text { this }\end{array}$ & $\begin{array}{l}\text { 个... } \\
\text { i ge... } \\
\text { s item }\end{array}$ & $\begin{array}{l}\text { 这 } \\
\text { zhèi } \\
\text { this }\end{array}$ & $\begin{array}{l}\text { 个... } \\
\text { ge... } \\
\text { item }\end{array}$ & $\begin{array}{l}\text { 穿 } \\
\text { chuān } \\
\text { put.on }\end{array}$ & $\begin{array}{l}\text { 上 } \\
\text { shang } \\
\text { up }\end{array}$ & $\begin{array}{l}\text { 之后 } \\
\text { zhīhòu } \\
\text { after }\end{array}$ \\
\hline $\begin{array}{l}\text { 这 } \\
\text { zhèi } \\
\text { this }\end{array}$ & $\begin{array}{l}-\bar{y} \\
\text { yì } \\
\text { one }\end{array}$ & $\begin{array}{l}\text { 宿 } \\
\text { xiǔ } \\
\text { night }\end{array}$ & $\begin{array}{l}\text { 就 } \\
\text { jiu } \\
\text { just }\end{array}$ & $\begin{array}{l}\text { 待 } \\
\text { dài } \\
\text { be.in }\end{array}$ & $\begin{array}{l}\text { 冰 } \\
\text { bīng } \\
\text { ice }\end{array}$ & $\begin{array}{l}\text { 上 } \\
\text { shang, } \\
\text { up }\end{array}$ \\
\hline $\begin{array}{l}\text { 水 } \\
\text { shuǐ } \\
\text { water }\end{array}$ & $\begin{array}{l}\text { 上 } \\
\text { shang } \\
\text { up }\end{array}$ & $\begin{array}{l}\text { 站 } \\
\text { zhàn } \\
\text { stand }\end{array}$ & $\begin{array}{l}\text { 着, } \\
\text { zhe, } \\
\text { DUR }\end{array}$ & $\begin{array}{l}\text { 这 } \\
\text { zhèi } \\
\text { this }\end{array}$ & $\begin{array}{ll}\text { 一 } & \text { 宿 } \\
\text { yi } & \text { xiŭ } \\
\text { one } & \text { night }\end{array}$ & \\
\hline $\begin{array}{l}\text { e, zh } \\
\text { UR thi }\end{array}$ & iis sh & $\begin{array}{l}\text { 这 } \\
\text { zhè } \\
\text { this }\end{array}$ & $\begin{array}{l}\text { 脚 } \\
\text { jiăo } \\
\text { feet }\end{array}$ & $\begin{array}{l}\text { 也 } \\
\text { yẽ } \\
\text { also }\end{array}$ & $\begin{array}{l}\text { 不 } \\
\text { bu } \\
\text { not }\end{array}$ & \\
\hline
\end{tabular}

'After he eh... eh... put them on, he stood the whole night on the ice... on the water, he stood all night and because of his shoes... his feet did not get cold at all.'

In sentence (12), the language consultant recalls a traditional Manchu wedding. According to custom, after the marriage the bride had to sit on a bed for three days, not stepping on the ground for a single moment.

（12） 就 跟 床上坐着, 不能下地。 Jiu gēn chuáng shang zuò zhe, bù néng xià dì. just follow bed up sit DUR not be.able down earth 'So she was sitting on the bed and could not step on the ground.' 
Chirkova K. \& Lamarre C. / Cahiers de Linguistique - Asie Orientale 34(2005) 169-220

Sentence (13) describes Manchu funeral rituals.

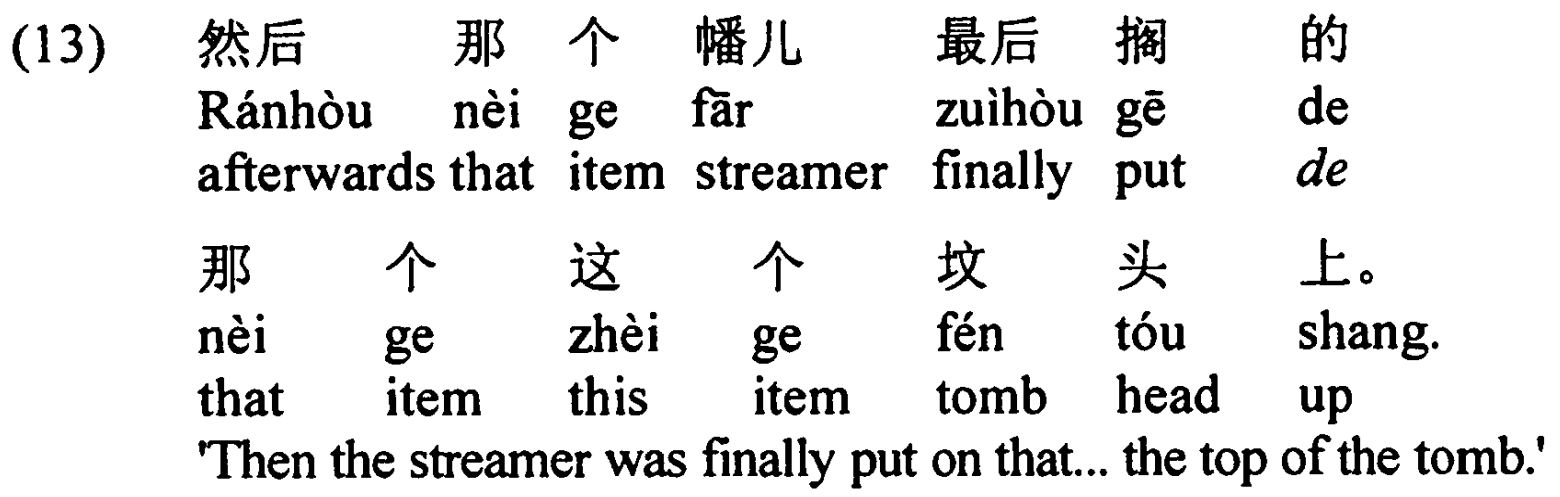

Preverbal locative phrases introduced by dăi dài 'be in', āi ăi 'be next or near to', and gèn 'on' denote location of an action. When used with verbs followed by the durative particle zhe, the whole construction denotes a durative state, e.g. examples (11) and (12). The meaning of postverbal locative phrases introduced by de, on the other hand, is terminative. Given that dăi dài, āi $\sim a ̆ i$ and gēn cannot be used postverbally, and de cannot be used preverbally, the position of a locative phrase in the sentence (preverbal or postverbal) and its meaning (durative or terminative) in the Beijing dialect of Mandarin are linked.

Zhū (1987: 328-329) and Hú (1991: 42) claim that the Beijing dialect of Mandarin does not originally use zài as a coverb, using instead dăi dài, āi ăa , and gēn with preverbal locative phrases and de with postverbal locative phrases. Zài as a coverb is allegedly borrowed into the Beijing dialect of Mandarin from the written language. Zài is often considered to be the universal locative coverb of the written language that can be used both preverbally and postverbally (cf. Guō 1986: 20). In Zhū and Hú's analysis, the use of the coverb zài is a feature of the written language and until recently was not typical for the spoken language of the capital. Zhū also notes (1987:329) that educated speakers of the Beijing dialect of Mandarin tend to use the coverb zài mostly preverbally, while postverbally they have a preference for $d e$. Based on this observation, we conclude that a clear distribution between 
The paradox of the construction [V zai $\left.\mathrm{NP}_{\mathrm{LOC}}\right]$... / CLAO 34(2005) 169-220

forms that introduce preverbal, i.e. dăi dài, āi ăi, gēn and zài, and postverbal locative phrases, i.e. de, was typical for the Beijing dialect of Mandarin of the late 1980s.

A similar distribution is also characteristic of the corpus of Beijing Mandarin used for this study: the coverb zài is used almost exclusively preverbally, as in the following example:

我们 在 城里 住, 不 在 这儿 住。
Wŏmen zài chéngli zhù, bú zài zhèr zhù.
IP be.in city.inside live not be.in here live
'We live downtown, not here.'

Older language consultants do not use zài postverbally unless with bisyllabic verbs. The occurrence of zài postverbally with bisyllabic verbs, as in example (15), is due to the fact that bisyllabic verbs are generally felt to belong to the realm of the written language (Peyraube 1980: 136, Xú 1994a: 342-343) and for this reason tend to combine with the written style using postverbal coverb zài, as in the next sentence:

$$
\begin{aligned}
& \text {...所以 我 父亲 把 希望 都 寄托 在 } \\
& \text {... suóyi wŏ fùqin bă xīwàng dōu jìtuō zai } \\
& \text { therefore 1S father PTR hope all consign be.in } \\
& \begin{array}{lll}
\text { 我 } & \text { 身 } & \text { 上... } \\
\text { wo } & \text { shēn } & \text { shang... }
\end{array} \\
& \text { 1S body up } \\
& \text { '... therefore my father set all his hopes on me...' }
\end{aligned}
$$

Table 1 summarizes the frequency of the preverbal and postverbal occurrences of zài zai in the speech of nine language consultants of various age groups, totalling seven recording sessions. The number of occurrences of the forms dao and de is included in the table for comparison. The total of sentences in these seven sessions amounts to approximately one quarter of the corpus. 
Chirkova K. \& Lamarre C. / Cahiers de Linguistique - Asie Orientale 34(2005) 169-220

It is worthy of note that in those few instances where zai is used postverbally, it is more often than not terminative. One formal evidence of this is the frequent use of postverbal zai in the so-called bă-construction or disposal sentence ( 3 out of the total of 19 postverbal usages of zai in Table 1). Notably, the bă-construction usually encodes a change of state, or - in our examples - a change of location. ${ }^{10}$ This usage is illustrated in the next sentence.

Table 1. Frequency of preverbal and postverbal occurrences of zài zai and of the postverbal occurrences of dao and de

\begin{tabular}{|c|c|c|c|c|}
\hline $\begin{array}{l}\text { language consultant } \\
\text { (age): session length } \\
\text { (sentences) }\end{array}$ & $\begin{array}{l}\text { preverbal } \\
\text { occurrences } \\
\text { of } z \grave{a} i\end{array}$ & $\begin{array}{l}\text { postverbal } \\
\text { occurrences } \\
\text { of zai }\end{array}$ & $\begin{array}{c}\text { postverbal } \\
\text { occurrences } \\
\text { of de }\end{array}$ & $\begin{array}{c}\text { postverbal } \\
\text { occurrences } \\
\text { of dao }\end{array}$ \\
\hline Tián (86 years old): 165 & 6 & $\varnothing$ & 3 & $\varnothing$ \\
\hline Liú (83 years old): 1267 & 44 & $2^{i}$ & 33 & $\varnothing$ \\
\hline Fù (76 years old): 964 & 23 & 1 & 4 & $\varnothing$ \\
\hline Zhāng ( $>70$ years old): 795 & 33 & 2 & 28 & $\varnothing$ \\
\hline $\begin{array}{l}\text { Wāng (> } 40 \text { years old): } \\
737\end{array}$ & 33 & 8 & 13 & $\bar{\varnothing}$ \\
\hline $\begin{array}{l}\text { Zhào, Zhōu, Liú, Zhāng } \\
\text { (all } 15 \text { years old): } 433\end{array}$ & 15 & 2 & 1 & $\varnothing$ \\
\hline $\begin{array}{l}\text { Zhào, Zhōu, Liú, Zhāng } \\
\text { (all } 15 \text { years old): } 369\end{array}$ & 10 & 4 & $\varnothing$ & 1 \\
\hline Total & 164 & 19 & 82 & 1 \\
\hline
\end{tabular}

${ }^{1}$ used in the written language style, as in sentence (15)

$\begin{array}{llllll}\text { 然后 他 } & \text { 把 } & \text { 乌龟 } & \text { 放 } & \text { 在 } & \text { 我们 } \\ \text { Ránhòu tā } & \text { bă } & \text { wūguĩ } & \text { fàng } & \text { zai } & \text { wǒmen } \\ \text { afterwards } & 3 & \text { PTR } & \text { turtle } & \text { put } & \text { be.in } 1 P\end{array}$

\footnotetext{
${ }^{10}$ This is sometimes expressed by the term "disposal meaning", cf. Li and Thompson (1981: 468-470). Hopper and Thompson (1980) note that this construction requires "a perfectivizing expression, either a perfective particle or a phrase or clause specifying the conceptual boundary of the action." The perfective meaning noted here corresponds roughly to what we call terminative.
} 
The paradox of the construction [V zai $\left.\mathrm{NP}_{\mathrm{Loc}}\right]$... / CLAO 34(2005) 169-220

$\begin{array}{llll}\text { 院儿 } & \text { 里 } & \text { 地 } & \text { 上。 } \\ \text { yuàr } & \text { li } & \text { dì } & \text { shang. } \\ \text { yard } & \text { inside } & \text { earth } & \text { up }\end{array}$

'Then he put the turtle on the ground in our yard.'

With postverbal locative phrases, the Beijing dialect of Mandarin also uses, besides de and zài, the coverb dao 'arrive' and the zero form. The latter is often seen as an omission of dao or zai (Peyraube 1980: 134-148, Guō 1986: 22, Xú 1994b: 180). The use of dao in the corpus is illustrated in sentence (17):

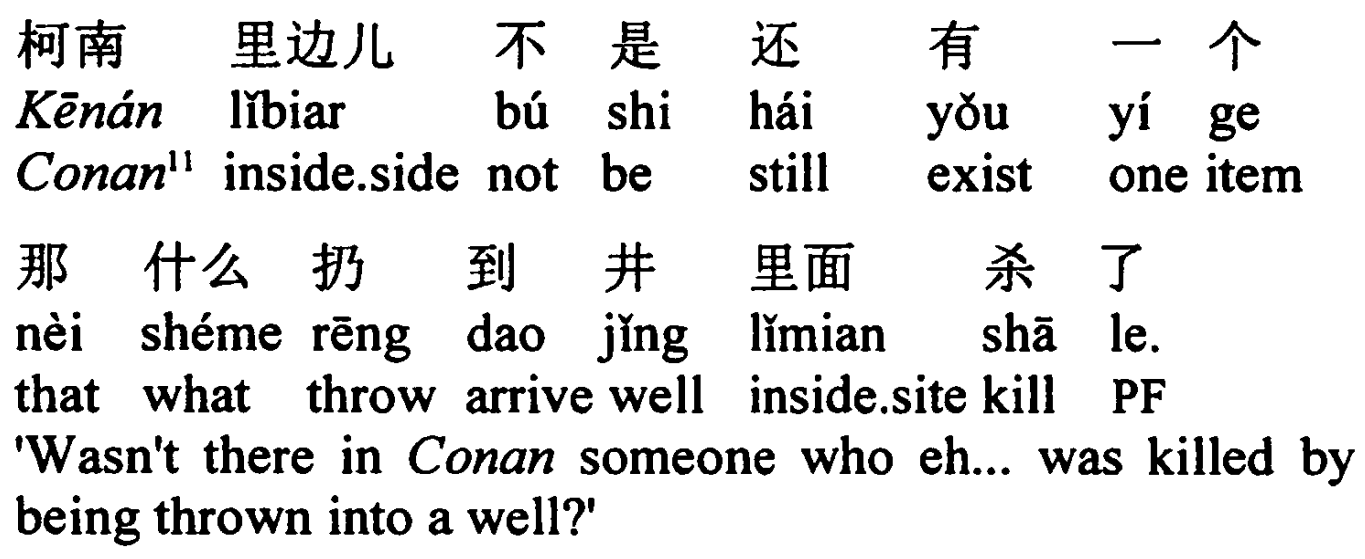

Sentence (18) illustrates the use of the zero form:

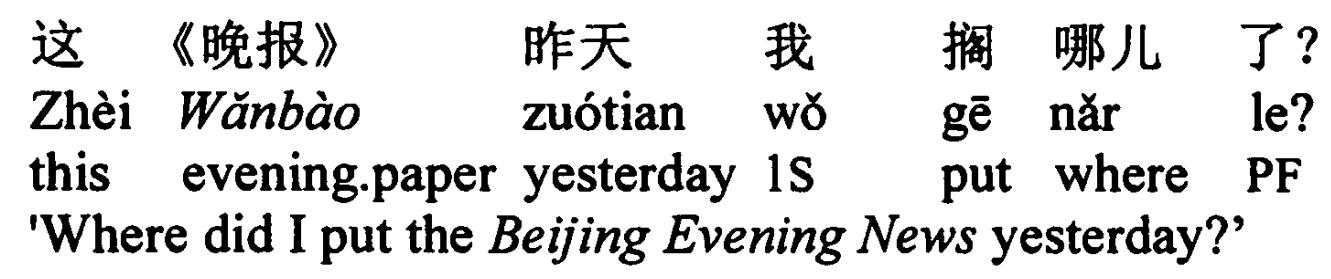

The relationship between various forms used with postverbal locative phrases, i.e. zai, dao, de and zero form, is complex. Zai and dao are mainly treated as locative coverbs of the written language, whereas the form $d e$ and the zero form are considered more typical of the spoken register.

${ }^{11}$ Conan is the name of a Japanese cartoon, shown on Chinese television in 2000-2001. 
Chirkova K. \& Lamarre C. / Cahiers de Linguistique - Asie Orientale 34(2005) 169-220

According to Peyraube (1981: 136), who bases his observations on Beijing Mandarin data collected in the 1970s, the postverbal $z a i$ tends to be used in the spoken language with bisyllabic verbs. He explains this by the fact that bisyllabic verbs rarely occur in the spoken language. This observation is corroborated by Guo (1986: 22). Both remark that the co-occurrence of the postverbal zai with bisyllabic verbs is due to the niveau de langue of the verb rather than to its mere prosodic constraints, and quote as evidence a few colloquial Beijing Mandarin bisyllabic verbs, which admit such an omission.

Guō (1986: 22), Xú (1994b: 1994) and Zhào (1995: 3) argue that $z a i$ does not occur in the postverbal locative phrase followed by the directional verbs lai 'come' or $q u$ 'go'. In contrast with the written language, zai may co-occur with the directional verbs lai and $q u$ in the spoken language, as shown in the following example. ${ }^{12}$ In this sentence, the language consultant recalls festivities around the Chinese New Year in her childhood. Steamed buns and various dishes used to be prepared well before the New Year and stored outside, in the cold.

\begin{tabular}{|c|c|c|c|c|c|c|}
\hline (19) & $\begin{array}{ll}\text { 然后 } & \text { 就 } \\
\text { Ránhòu } & \text { jiu } \\
\text { afterwards } & \text { just }\end{array}$ & $\begin{array}{l}\text { 搁 } \\
\text { gè } \\
\text { put }\end{array}$ & $\begin{array}{l}-\bar{y} \\
\text { yí } \\
\text { one }\end{array}$ & $\begin{array}{l}\text { 个 } \\
\text { ge } \\
\text { item }\end{array}$ & $\begin{array}{l}\text { 大 } \\
\text { dà } \\
\text { big }\end{array}$ & $\begin{array}{l}\text { 盆儿 } \\
\text { pér } \\
\text { pot }\end{array}$ \\
\hline & $\begin{array}{ll}\text { 里头, } & \text { 拿 } \\
\text { lǐtou, } & \text { ná } \\
\text { inside } & \text { take }\end{array}$ & $\begin{array}{l}\text { yí } \\
\text { one }\end{array}$ & $\begin{array}{l}\text { 个 } \\
\text { ge } \\
\text { item }\end{array}$ & $\begin{array}{l}\text { 布 } \\
\text { bù } \\
\text { cloth }\end{array}$ & $\begin{array}{l}- \\
\text { yí } \\
\text { one }\end{array}$ & $\begin{array}{l}\text { 盖, } \\
\text { gài, } \\
\text { cover }\end{array}$ \\
\hline & $\begin{array}{ll}\text { 也 } & \text { 是 } \\
\text { ye } & \text { shi } \\
\text { also } & \text { be }\end{array}$ & $\begin{array}{l}\text { 搁 } \\
\text { gē } \\
\text { put }\end{array}$ & $\begin{array}{l}\text { 在 } \\
\text { zai } \\
\text { be.in }\end{array}$ & $\begin{array}{l}\text { 外边, } \\
\text { wàibi } \\
\text { outsic }\end{array}$ & side & $\begin{array}{l}\text { 去。 } \\
\text { qu. } \\
\text { go }\end{array}$ \\
\hline
\end{tabular}

${ }^{12}$ Similar examples with the verb 悯 ge 'to put' can be found in Yànjīng fûyŭ. See for instance Lesson 7. 
The paradox of the construction $\left[\mathrm{V}\right.$ zai $\left.\mathrm{NP}_{\mathrm{LOC}}\right] \ldots /$ / CLAO 34(2005) 169-220

In contrast with other forms that introduce postverbal locative phrases in the corpus, dao is infrequent and occurs only in six sentences out of almost 18,000 of the corpus. It is restricted to those instances where the direction of the motion needs to be emphasized. In the following sentence, the language consultant recalls how he grazed sheep on the top of the city wall that used to encircle Beijing. While grazing sheep, he was doing his school assignments and was following the sheep as they moved from one gate to the other.

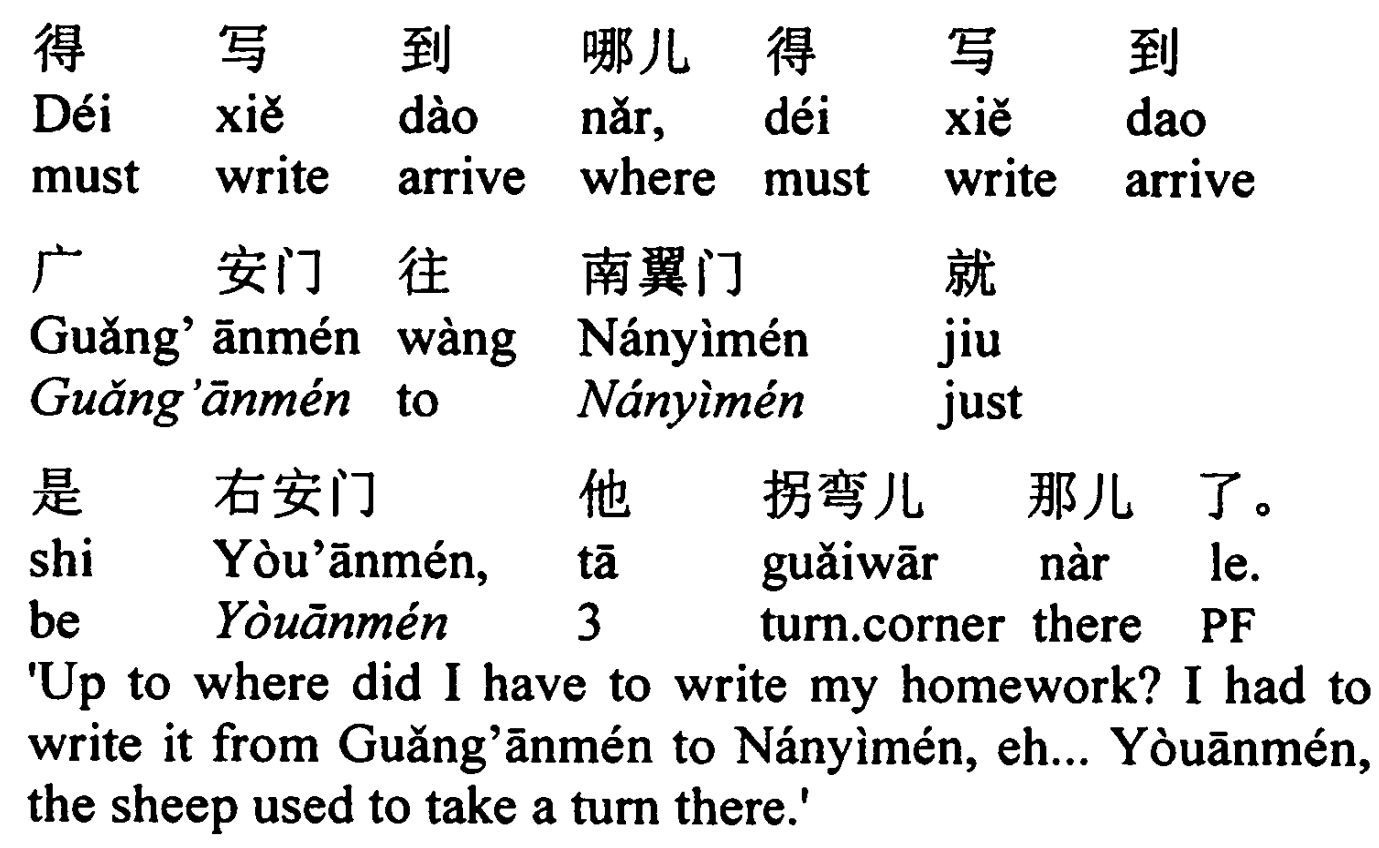

The form $d e$ is sometimes considered as a blend of the written coverbs $z a i$ and dao in the spoken language (Chao 1968: 353-354, 106-107, Dragunov 1958: 71-72, Guō 1986: 20, Zhū 1961: 1, 1982:182) or, alternatively, as a neutralization of the coverb dao (Xú 1994b: 183) or also of $z$ he (Jiāng 1994, Yuán 2002, see also § 1.2). The exact nature of the relationship between zai, dao, on the one hand, and the form de and the zero form, on the other, is currently unclear. Is the form de a neutralization of the written forms zài and dào? Is the zero form an omission of zài or dào? Do the coverbs zài and dào, when used postverbally in the written language, automatically transform into the form de (or the zero form) in the spoken language? As noted by Xú 


\section{8}

Chirkova K. \& Lamarre C. / Cahiers de Linguistique - Asie Orientale 34(2005) 169-220

(1994a: 182), there are no systematic recordings of the spoken language that can demonstrate that the written locative coverb zài automatically changes to de. All forms, zai, dào, de, dao and zero form have been attested in the corpus. This clearly shows that zai and dao do not automatically change into the form de in the spoken language, as is sometimes suggested.

As shown in Table 1, the form de is one of the preferred ways to introduce postverbal locative phrases for older speakers. Overall in the corpus, the use of de steadily decreases in the speech of younger language consultants, whereas the use of zai in their speech increases. However, the rate of postverbal occurrences of zai is relatively low for all age groups. Statistics for the occurrences of these coverbs (and the zero form) with verbs selected for analysis will be given in the following sections.

\subsection{Verbs selected for analysis}

The range of verbs that can potentially have a double interpretation (durative or terminative) with the postverbal locative phrase varies according to different grammars of Standard Mandarin. We have opted for the broadest range of verbs possible and have searched for all verbs mentioned in standard reference grammars of Mandarin, Charles N. Li and Sandra A. Thompson's Mandarin Chinese: A functional reference grammar (1981) and Liú Yuèhuá et al. Shíyòng xiàndài Hànyŭ yúfă / Chinese grammar (1983), as well as in articles on locative phrase position and meaning, Wáng Huán's "Shuō zài" (1957), James H.-Y. Tai's "On the two functions of place adverbials in Mandarin Chinese" (1975) and Fàn Jiyān's "Lùn jiècí duányŭ 'zai + chùsuǒ"' [On the prepositional phrase 'zài + location'] (1982). This section is based on $\mathrm{Li}$ and Thompson's description, which is one of the most detailed.

$\mathrm{Li}$ and Thompson divide verbs that allow both preverbal and postverbal positioning of a locative phrase into four groups: 
The paradox of the construction $\left[\mathrm{V}\right.$ zai $\left.\mathrm{NP}_{\mathrm{LOC}}\right] \ldots /$ / CLAO 34(2005) 169-220

(i) Verbs of displacement, i.e. verbs "whose meaning includes the local displacement of either the subject (in the case of intransitive verb) or the direct object (in the case of the transitive verb)" (1981: 398, original italics), e.g. 扔 rēng 'toss', 推 tuī 'push', 掉 diào 'drop, fall', 拔 $b \bar{o}$ 'sprinkle', 摔 shuāi 'fall, trip', 倒 dăo 'fall', 流 liú 'flow', 爬 pá 'crawl'.

(ii) Verbs of posture, e.g. 站 zhàn 'stand', 睡 shuì 'sleep', 爬 pá 'crouch', 蹲 dūn 'squat', 停 tíng 'stop', 坐 zuò 'sit', 躺 tăng 'lie', 䟦 guì 'kneel', 住 zhù 'have residence', 漂 piāo 'float' (1981: 401).

(iii) Verbs of appearing, e.g. 发生 fäshēng 'happen, occur', 出现 chüxiàn 'appear', 出生 (chü)shēng 'be born', 生长 shēngzhăng 'grow up', 长大 zhăngdà 'grow up' (1981: 403).

(iv) Verbs of placement, i.e. verbs "whose meaning includes the local displacement of either the subject (in the case of intransitive verb) or the direct object (in the case of a transitive verb)" (ibid., p. 398, original italics), e.g. 放 fâng 'put, place', 种 zhòng 'plant', 画 huà 'draw, paint', 吐 tù 'expectorate', 刻 $k e ̀$ 'carve, sculpt', 撒 $s \bar{a}$ 'spill', 藏 cáng 'hide', 写 xiě 'write', 抄 chāo 'copy', 印 yìn 'print' (1981: 404, original italics).

Of these four categories, verbs of appearing are irrelevant for the present survey, given that all of them are bisyllabic and as such, they are more typical for the written rather than for the spoken language.

Having searched for all these verbs in the corpus and having eliminated those that do not occur, we have narrowed down the range of the verbs for the present survey to the following eight intransitive and thirteen transitive verbs: ${ }^{13}$

${ }^{13}$ This inventory roughly corresponds to the verbs of posture and placement appearing in the [V zai $\mathrm{NP}_{\mathrm{Loc}}$ ] and [zài $\mathrm{NP}_{\mathrm{Loc}} \mathrm{V}$ zhe] constructions in the two 
Chirkova K. \& Lamarre C. / Cahiers de Linguistique-Asie Orientale 34(2005) 169-220

Table 2 - Intransitive and transitive verbs selected for analysis

\begin{tabular}{|l|l|}
\hline \multicolumn{1}{|c|}{ Intransitive } & \multicolumn{1}{c|}{ Transitive } \\
\hline 蹲 $d \bar{u} n$ 'squat' & 摆 băi 'display' \\
跍 guì 'kneel' & 堆 $d u \overline{~ ' p i l e ~ u p ' ~}$ \\
爬 pá 'crawl' & 躲 duó 'hide' \\
漂 piāo 'float' & 放 fàng 'put, place' \\
躺 tăng 'lie' & 搁 gē 'put, place' \\
站 zhàn 'stand' & 挂 guà 'hang' \\
住 zhù 'live, take up & 埋 mái 'bury' \\
residence' & 扔 rēng 'toss' \\
坐 zuò 'sit' & 锁 suǒ 'lock' \\
& 贴 tiē 'stick' \\
& 停 tíng 'stop' \\
& 写 xiě 'write' \\
& 装 zhuāng 'install' \\
\hline
\end{tabular}

2.3. Criteria for sentence selection

The following sentences that contain these verbs have been selected for analysis:

(a) Only sentences that allow both preverbal and postverbal placement of locative phrases have been selected. This implies that each of the selected sentences can be transformed by shifting the locative construction that it contains either preverbally (if it is originally used postverbally) or postverbally (if it is originally used

corpora reflecting late Qing Beijing Mandarin described in Lamarre (2003a). Guānhuà zhínán also includes the verbs 归 guï 'gather', 押 yā 'mortgage', 枷号 jiāhào 'shackle', 湾 wān 'cast anchor', 插 chā 'insert', 搭 dā 'put up, build', 藏 cáng 'hide', 折 zhé 'fold', 叙 $x \grave{u}$ 'relate (by writing)', 掖 $y \bar{e}$ 'tuck in', 铺 $p \bar{u}$ 'spread', 繁 shā 'tighten', 胯 kuà 'step, bestride', 拴 shuān 'fasten', and 寄放 jifang 'leave (in the care of someone)'. In addition, Yànjing füyú also comprises the verbs 晒 shài 'dry in the sun', 种 zhòng 'plant', and 收 shöu 'put away, bring in'. 
The paradox of the construction $\left[\mathrm{V}\right.$ zai $\left.\mathrm{NP}_{\mathrm{Loc}}\right] \ldots /$ / CLAO 34(2005) 169-220

preverbally). For example, the expression nàr guà de 'hanging there' in sentence (21) can be transformed to guà zai nàr de.
你 就 喜欢 名人
字画,
那儿挂 的...
Nǐ jiu xîhuan míngrén
zìhuà,
nàr guà de...
$2 S$ just like famous.people calligraphy.scroll there hang SUB
'You like calligraphy and paintings of renowned artists, hanging there...'

Given that in each case, speakers have two possible positions for the locative phrase, it allows us to examine the choice they make based on the meaning (durative or terminative) they wish to express. Thus, in the sentence above, the speaker chooses preverbal positioning of the locative phrase to express the durative event of hanging.

Note that when the locative phrase is placed before one of the 13 transitive verbs chosen for the present analysis, the sentence can express either a durative or a terminative situation. In the former case, the verb often takes the durative particle zhe. In the latter case, the verb can be followed by the perfective particle le or, alternatively, it is not accompanied by any aspectual particle at all, as in the following example. In this sentence, the speaker explains how fake antiques can be aged artificially.

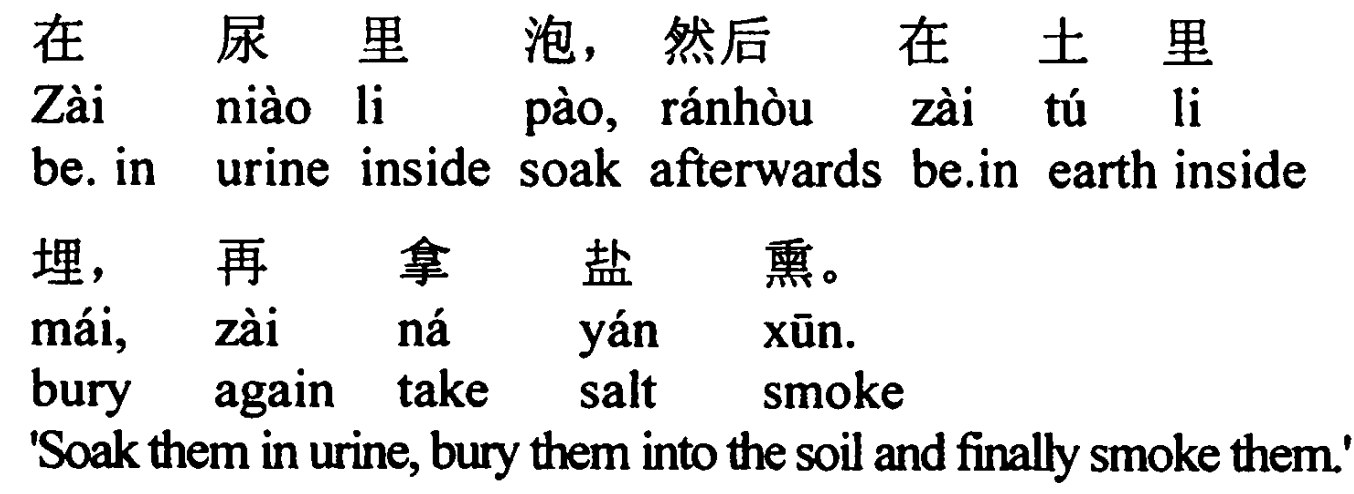

In example (23), the speaker who is afraid of theft on public transport explains that he always spreads the money he carries on himself over several pockets. 
Chirkova K. \& Lamarre C. / Cahiers de Linguistique - Asie Orientale 34(2005) 169-220

...反正

... fănzhèng in.any.case
这 都 是 卿儿, zhè dōu shì dōur, this all be pocket
都 dōu

all
是啊, shì $a$, be eh

这儿 搁 点儿, 那儿搁 点儿, 这么 着。 zhèr gē diăr, nàr gē diăr, zhème zhe. here put a.little there put a.little so DUR '... in any case, I've got plenty of pockets here, these are all pockets, so I put some money here and some more there, like that.'

Given that the main goal of this article is to investigate the meaning of postverbal locative phrases, sentences including preverbal locative phrases are taken into account only for the sake of comparison. This is why we have excluded those sentences, where the verb denotes an action, e.g. examples (22) and (23), and selected those that express a durative situation of 'being placed or situated somewhere', as in the following example. In this sentence, the language consultant talks about treasures kept at the Băilin Temple in Beijing.

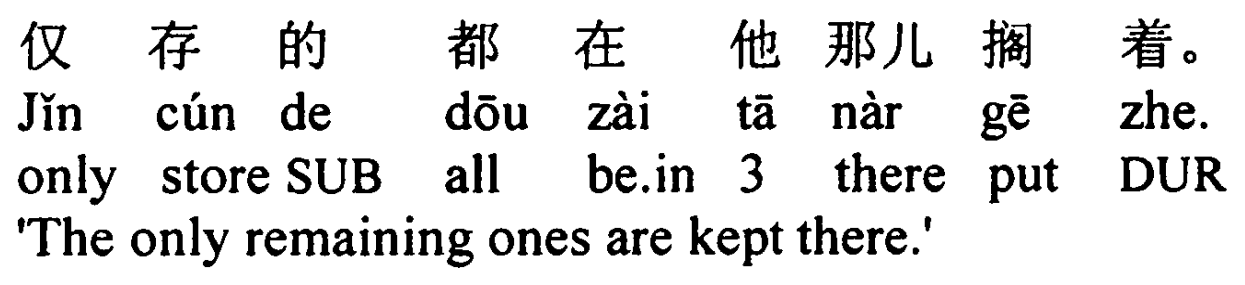

(b) Verbal phrases, followed or preceded by a locative phrase, used as modifiers have likewise been selected for analysis. For example:

\begin{tabular}{|c|c|c|c|c|c|c|}
\hline (25) & $\begin{array}{ll}\text { 牛街 } & \text { 我 } \\
\text { Niújiē } & \text { wǒ } \\
\text { Niújiēe } & 1 \mathrm{~S}\end{array}$ & $\begin{array}{l}\text { 说 } \\
\text { shuō } \\
\text { speak }\end{array}$ & $\begin{array}{l}\text { 过 } \\
\text { guo } \\
\text { EXP }\end{array}$ & $\begin{array}{l}\text { 这 } \\
\text { zhèi } \\
\text { this }\end{array}$ & $\begin{array}{l}\text { 个, } \\
\text { ge, } \\
\text { item }\end{array}$ & $\begin{array}{l}\text { 但是 } \\
\text { dànshi } \\
\text { but.be }\end{array}$ \\
\hline & $\begin{array}{l}\text { 呢 在 } \\
\text { ne zài } \\
\text { RLV be.in }\end{array}$ & $\begin{array}{l}\text { 那儿哈儿 } \\
\text { nàrher } \\
\text { there }\end{array}$ & $\begin{array}{l}\text { 住 的 } \\
\text { zhù de } \\
\text { live SUB }\end{array}$ & $\begin{array}{l}\text { 汉族 } \\
\text { Hàn } \\
\text { 3 Hàn }\end{array}$ & $\begin{array}{l}\text { 人 } \\
\text { urén } \\
\text { lationa }\end{array}$ & \\
\hline
\end{tabular}


The paradox of the construction $\left[\mathrm{V}\right.$ zai $\left.\mathrm{NP}_{\mathrm{Loc}}\right]$... / CLAO 34(2005) 169-220

$\begin{array}{llll}\text { 有, } & \text { 为 数 } & \text { 不 } & \text { 多。 } \\ \text { yǒu, wéshù } & \text { bù } & \text { duō. } \\ \text { exist } & \text { be.number } & \text { not } & \text { much }\end{array}$

'Even though, as I said, there are some Hàn Chinese living in Niújiē, they are not numerous.'

This sentence allows the transformation outlined in (a), i.e the expression zài nàrher zhù de Hànzúrén can be transformed to zhì zai nàrher de Hànzúrén.

(c) Set constructions such as 坐车 zuò chē' 'ride in a car, go by car', 坐轿子 zuò jiàozi 'take a sedan chair', or 住院 zhù yuàn 'be hospitalized' have not been selected, whereas constructions such as 坐在骄子里边儿 zuò zai jiàozi libiar, literally, 'sit inside a sedan chair', as in sentence (26), or 在院里住着 zài yuàn li zhù zhe 'staying in (literally, inside) a hospital' have been selected. In the former type of expressions, the substantive does not behave as a place word (cf. Chao 1968: 519-33, Peyraube 1980: 138) and the compound is highly lexicalized (and often listed as a set construction in dictionaries). Alternatively, in the latter type, the

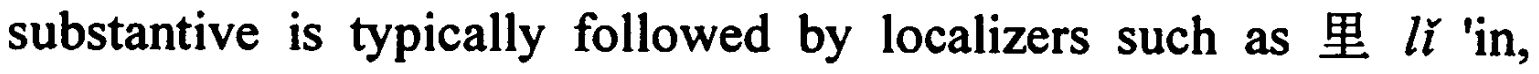
inside', 上 shàng 'up, above', 下 xià 'below', 外 wài 'outside', 前 qián 'in front' and 后 hòu 'behind' (cf. Chao 1968: 620-7, Peyraube 1980: 138).

\begin{tabular}{|c|c|c|c|c|}
\hline $\begin{array}{ll}\text { 她 } & \text { 就 } \\
\text { Tā } & \text { jiu } \\
3 & \text { jus }\end{array}$ & $\begin{array}{l}\text { 坐 } \\
\text { zuò } \\
\text { sit }\end{array}$ & $\begin{array}{l}\text { 在 } \\
\text { zai } \mathrm{J} \\
\text { inside }\end{array}$ & $\begin{array}{l}\text { 骄子 } \\
\text { jiàozi } \\
\text { sedan.chair }\end{array}$ & $\begin{array}{ll}\text { 里边儿 } & \text { 压 } \\
\text { líbiar } & \text { yā } \\
\text { inside.side press }\end{array}$ \\
\hline $\begin{array}{l}\text { 然后 } \\
\text { ránhòu } \\
\text { then }\end{array}$ & $\begin{array}{l}\text { 到 } \\
\text { dào } \\
\text { arrive }\end{array}$ & $\begin{array}{l}\text { 我们 } \\
\text { worme } \\
1 P\end{array}$ & $\begin{array}{l}\text { 家 } \\
\text { len jiā } \\
\text { home }\end{array}$ & $\begin{array}{l}\text { 来。 } \\
\text { lái. } \\
\text { come } \\
\text { dan. }\end{array}$ \\
\hline
\end{tabular}


Chirkova K. \& Lamarre C. / Cahiers de Linguistique - Asie Orientale 34(2005) 169-220

(d) Existential sentences, i.e. those that contain the verb yŏu 'exist' or a verb of posture as the main verb and that describe where something has been put or placed (cf. Li and Thompson 1981: 510), have likewise not been chosen as not allowing for the transformation outlined in (a). For instance:

$\begin{array}{llllll}\text { 他 } & \text { 那儿 } & \text { 住 } & \text { 着 } & \text { 哥儿 } & \text { 俩。 } \\ \text { Tā } & \text { nàr } & \text { zhù } & \text { zhe } & \text { gēr } & \text { liă. } \\ 3 & \text { there } & \text { live } & \text { DUR } & \text { elder.brother } & \text { two.item }\end{array}$

'There were two brothers who lived at his place.'

(e) Sentences that express duration of the event or process under discussion, are not discussed, given that normally, this type of sentence does not allow both a duration and a locative phrase in the postverbal position. For example:

\begin{tabular}{llllll} 
我 跟 $\quad$ 家 & 住 & \multicolumn{1}{c}{ 了 } & 些 & 日子。 \\
Wǒ gèn jiā zhù le & xie & rìzi. \\
1s follow home live & PF & some & days \\
'I stayed at home for some time.' & &
\end{tabular}

2.4. Intransitive verbs: correlation between construction position and meaning

\subsubsection{Zhù 'live'}

In the Beijing dialect of Mandarin, the verb zhì 'live' has two distinct meanings: one is 'having residence' and the other 'taking up one's residence', cf. Oota (1958: 237, Chinese translation 1987: 223), Lamarre (2003a: 154). The former meaning is durative, whereas the latter meaning is terminative. In the Beijing dialect of Mandarin, the former meaning, i.e. having residence at a location, is usually rendered by placing the locative phrase before $z h \grave{u}$. The second meaning, i.e. taking up residence at a location, is indicated by placing the locative phrase after zhù. This division is strictly 
The paradox of the construction [V zai $\left.\mathrm{NP}_{\mathrm{LOC}}\right]$... / CLAO 34(2005) 169-220

observed in Guānhuà zhǐnán. ${ }^{14}$ For example, sentence (29) describes the situation of having long-term residence, whereas sentence (30) depicts the situation of taking up residence.

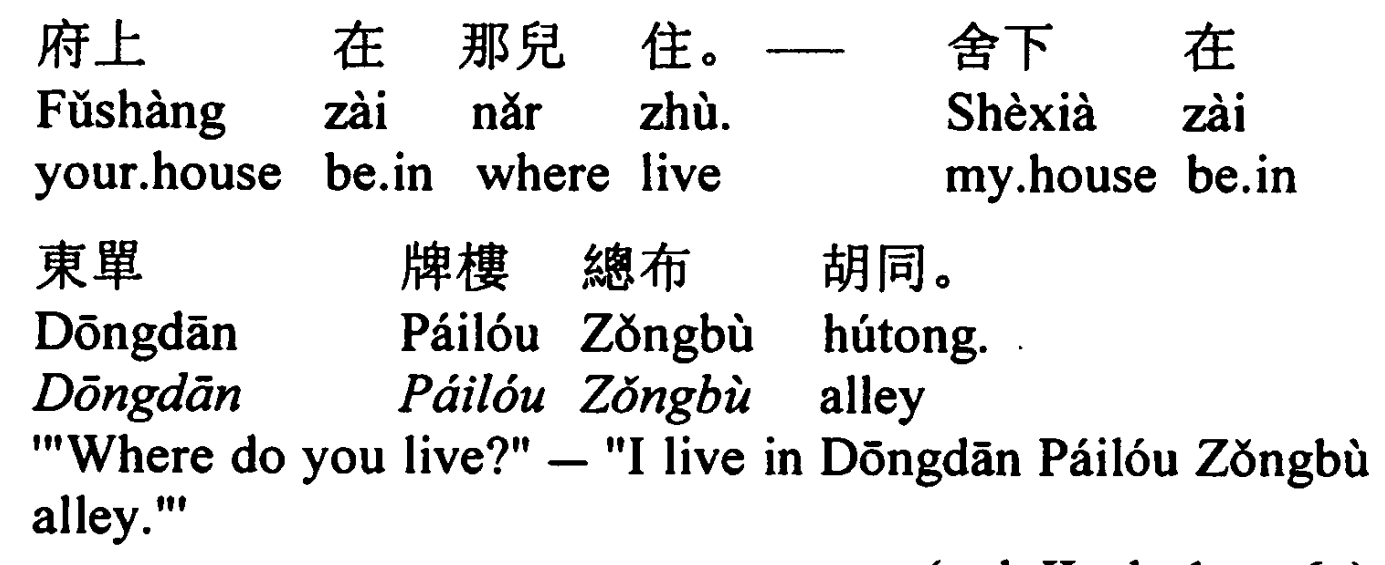

$$
\text { 今兒早起 火輪船到了, 他 就下 }
$$

Jinnr záoqì huǒlúnchuán dào le, tā jiù xià today morning steamboat arrive CRS 3 just go.down

\begin{tabular}{|c|c|c|c|c|}
\hline $\begin{array}{l}\text { 船 } \\
\text { chuán } \\
\text { boat }\end{array}$ & $\begin{array}{l}\text { 住 } \\
\text { zhù } \\
\text { live }\end{array}$ & $\begin{array}{l}\text { 在 } \\
\text { zai } \\
\text { be.in }\end{array}$ & $\begin{array}{ll}\text { 我們 } & \text { 棧 } \\
\text { wǒmen } & \text { zhàn } \\
\text { lP } & \text { shop }\end{array}$ & $\begin{array}{l}\text { 里 } \\
\text { li } \\
\text { inside }\end{array}$ \\
\hline
\end{tabular}

'The steamboat arrived this morning, after having disembarked he stopped at our hotel.'

(vol. II, ch. 21, p. 20a)

In the corpus, a similar division is still typical for the speech of older language consultants, who in the majority of cases choose the verb $z h i$, preceded by a locative phrase when talking about having residence at a location, and followed by a locative phrase when describing the event of taking up one's residence.

\footnotetext{
${ }^{14}$ Lamarre (2003a) notes that these sentences are regularly translated into the Shànghăi dialect of Tühuà zhĭnán 土话指南 (1908), using the opposite word order, i.e. 住 zhì 'live' followed by la, the Shànghăi equivalent of zai, and followed in turn by the locative phrase.
} 
Chirkova K. \& Lamarre C. / Cahiers de Linguistique - Asie Orientale 34(2005) 169-220

Table 3 demonstrates the frequency of co-occurrence of zhù with preverbal and postverbal locative phrases in the corpus. It also estimates correlation between construction position and meaning. The first number in each column represents the total of occurrences of $z h \dot{u}$ 'live' either with preverbal locative phrases or with de, zai or the zero form and postverbal locative phrases. For instance, zhuे cooccurs with the form de 12 times in the speech of older language consultants. The second number, given in square brackets, indicates the percentage of sentences for which construction position and meaning match (see $\S 1.5$ ).

Table 3. Correlation between construction position and meaning for 住 zhù 'live' in the corpus

\begin{tabular}{|c|c|c|c|}
\hline \multicolumn{2}{|c|}{ 住 zhù } & $\begin{array}{c}\text { Older } \\
\text { speakers }\end{array}$ & $\begin{array}{l}\text { Younger } \\
\text { speakers }\end{array}$ \\
\hline \multicolumn{2}{|c|}{ Pre-V: Durative 在/跟/ Ø $\mathrm{NP}_{\text {Loc }}$ 住（着） } & 35 & 8 \\
\hline \multirow[t]{3}{*}{$\begin{array}{l}\text { Post-V: } \\
\text { Terminative }\end{array}$} & Followed by 的 $d e$ & $12[33 \%]$ & $1[\varnothing \%]$ \\
\hline & Followed by 在 $z a i$ & $10[50 \%]$ & $9[11 \%]$ \\
\hline & Followed by $\varnothing$ & $19[63 \%]$ & $16[44 \%]$ \\
\hline \multicolumn{2}{|l|}{ Total } & 76 & 34 \\
\hline
\end{tabular}

In the following examples, the locative phrase is placed before the verb to express the meaning 'have residence'. Similar to the Beijing Mandarin reflected in Guānhuà zhìnán, zhù 'live' in the corpus sometimes does and sometimes does not take the durative particle $z h e$ :

(31) 回 头 让 您 说, 我 姓
Huí tóu ràng nín shuō, wǒ xìng 什么,
return head let you.HON speak 1s have.family.name what
叫 什么 多 $\quad$ 大 岁数 家 在 哪儿 住,
jiào shéme, duó dà suishu, jiā zài năr zhù,
be.called what how.much big age home be.in where live


The paradox of the construction [V zai $\left.\mathrm{NP}_{\mathrm{LOc}}\right]$... / CLAO 34(2005) 169-220

啊, 好, 完了到时候儿查你去。 a, hăo, wán le dào shíhour chá nĭ qu. eh good finish CRS arrive time check $2 S$ go 'And then they will ask you: "What's your name?" "How old are you?" "Where do you live?" eh... Well, and then after a while they will come to check you.'

（32）在 那儿 住着, 要唐山 不 地震

Zài nàr zhù zhe, yào Tángshān bú dizhèn be.in there live DUR if Tángshān not.be earthquake 呢也得住着呢。 ne yé děi zhù zhe ne. RLV also must live DUR RLV

'So she was at the hospital there and if not for the Tángshān earthquake, she would still be staying there.'

The following example illustrates the use of $z h \grave{u}$ with the postverbal locative phrase in the meaning 'stay (for a limited period) at' or 'take up one's residence at':

你什么… 怎么了 住 院? - 心脏 病,

Nĩ shéme... zěme le, zhù yuàn? - Xīnzàng bìng, 2S what how CRS live hospital heart disease 冠心 病。一住哪儿了? - 住的空总 医院了。 guànxīn bìng. - Zhù năr le? -Zhù de Kōngzơng yīyuàn le. coronary disease live where CRS live $d e$ air.central hospital CRS "What had happened to you that you were hospitalized?" - "Heart problems, coronary disease." - "What hospital were you in?" - "In the Central Air Force Hospital."'

This distinction between the two meanings of zhì is arguably currently being conflated in the speech of younger language consultants, presumably under the influence of Standard Mandarin via education and mass media. Nor is such a distinction typical for the 
Chirkova K. \& Lamarre C. / Cahiers de Linguistique - Asie Orientale 34(2005) 169-220

written language, where zhi followed by the postverbal locative phrase can indicate both the durative situation of having residence and the terminative event of taking up one's residence at a location. For instance, the first example that Xiàndài Hànyŭ cídiăn offers in its entry on $z h \grave{u}$ in the meaning jüzhù, zhùs ì 'reside' is 你住在什么 地方? Nì zhù zai shénme difang? 'Where do you live?' presumably inquiring where the listener has their residence (1996: 1645). To compare, the same meaning, i.e. 'Where do you live?' is given in the entry on 住 zhù in the Chinese-English dictionary (1912: 315-316) by Herbert Giles for the sentence with the preverbal locative phrase, viz. 你在那裏住? Nǐ zài náli zhù? (ibid., p. 316).

The following example taken from a session with a younger language informant illustrates the mismatch of construction position and meaning.

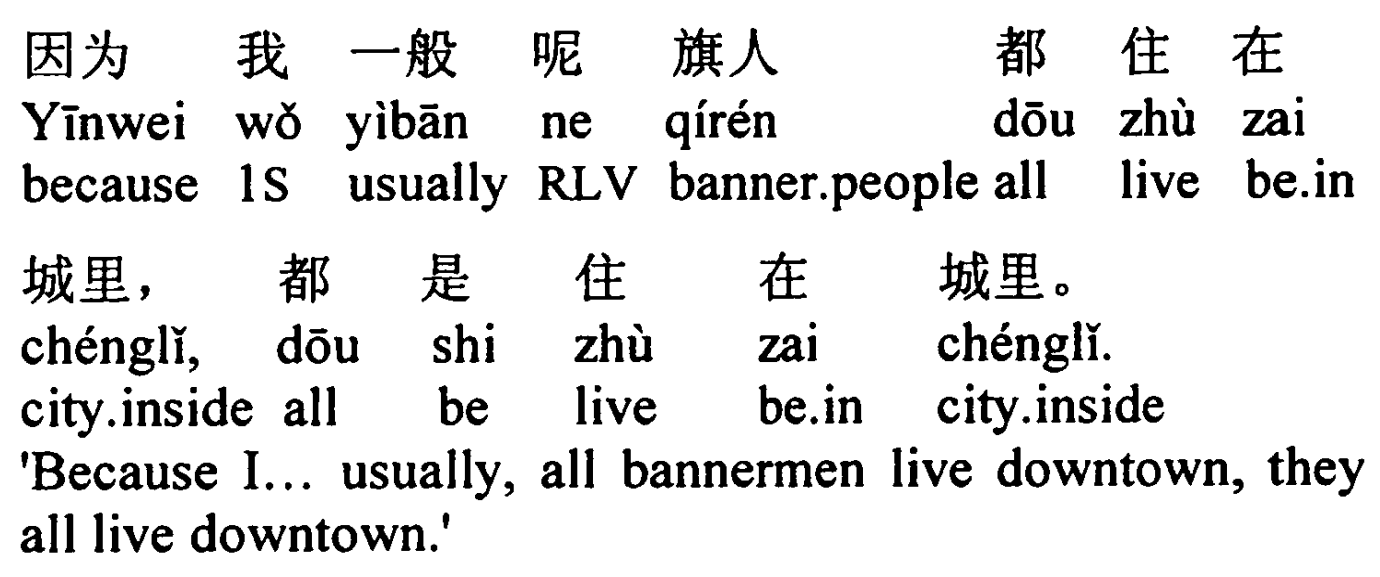

Zhōu Yīmin (2002: 144) quotes similar Beijing Mandarin examples, noting that $z a i$ 'be in' can alternate with the form de but not with dao 'arrive'.

2.4.2. Intransitive verbs as the first verb in a serial verb construction

An important distinction for a postverbal locative phrase construction to be taken into account in this analysis is between verbs occurring as the first verbal phrase in a serial verb construction and those used as the main verb. The main verb is the verb that defines 
The paradox of the construction $\left[\mathrm{V}\right.$ zai $\left.\mathrm{NP}_{\mathrm{LOC}}\right]$... / CLAO 34(2005) 169-220

the narrated time, i.e. the time of the situation spoken about in the sentence. By the term serial verb construction (or a V-V series), we understand two verbal expressions, usually with an object or a locative phrase after the first verb, juxtaposed and without any marker indicating the relationship between them, cf. Chao (1968: 300-301), Li and Thompson (1981: 594). A serial verb construction describes two separate events, of which the first can be completed before the second event (succession of two events in time, terminative reading for the first verbal phrase). Alternatively, the two events can be seen as overlapping in time, the first verb phrase describing the circumstances under which the event denoted by the second verb phrase occurs (durative reading for the first verbal phrase). For example, the construction zhàn zai nàr kàn le bàntiān can potentially be understood as 'having taken a position there I looked for a long time' (succession of two events in time, coordinate reading) or as 'while standing there I looked for a long time' (the first event serving as a background for the second event, subordinate reading). In a similar fashion, the expression tăng zai chuáng shang shuijiào can be read as 'sleep, having lain on the bed' or as 'sleep while lying on the bed'. In the absence of a locative phrase, the potential ambiguity can be clarified by using the perfective particle le after the first verb to signal that the first event is completed before the second event takes place (terminative meaning). For example, shü le xià cì zhēngqŭ 'strive for victory next time after having lost'. The particle $z$ he after the first verb, on the other hand, can be used to signal that the first event serves as a background for the second event (durative meaning). For example, ná zhe zhè dōngxi dào Běidà 'go with this thing to Beijing University', literally, 'go to Beijing University while carrying this thing'. The use of the postverbal locative phrase, however, precludes the use of these particles and both, terminative and durative, readings are therefore possible.

As noted by Chao (1968: 326), a serial verb construction favors the subordinate rather than coordinate reading for the first verbal phrase. In his analysis, the second verbal phrase is mostly viewed as having approximately the same function as the whole and 
Chirkova K. \& Lamarre C. / Cahiers de Linguistique -Asie Orientale 34(2005) 169-220

is the center to which the first verbal phrase is a modifier. In other words, in a serial verb construction without any markers after the first verb (as is the case with the postverbal locative phrase), the first verbal phrase tends to be interpreted as denoting an event that accompanies the event expressed by the second verbal phrase and overlaps with it in time, i.e. as denoting a durative meaning.

When the verb that serves as first in a V-V series is transitive, it is more readily seen as signaling an event that terminates after reaching the location denoted by the locative phrase. For example, the expression ge jiā lĭtou fangxin means 'feel relieved after having left it at home' rather than 'feel relieved while leaving it at home'. If the first verb in a series is intransitive, on the other hand, it is more readily seen as denoting a durative event serving as background for the event expressed by the second verbal phrase. For example, the expression zhàn zai nàr bù néng dòng is more likely to be understood as 'be unable to move while standing there', even though the reading 'be unable to move after having taken up a position there' is also possible.

With the exception of the verbs zhù 'live', dün 'squat' and gui 'kneel', all the intransitive verbs selected for analysis occur in the corpus mostly as the first verb in a serial verb construction, as shown in Table 4.

Table 4. Intransitive verbs in a serial verb construction

\begin{tabular}{|c|c|c|c|c|c|c|c|c|c|}
\hline Positi & erb & $\begin{array}{c}\text { 住 } \\
\text { zhù } \\
\text { 'live' }\end{array}$ & $\begin{array}{l}\text { 坐 } \\
z u o ̀ \\
\text { 'sit' }\end{array}$ & $\begin{array}{c}\text { 站 } \\
\text { zhàn } \\
\text { 'stand' }\end{array}$ & $\begin{array}{l}\text { 躺 } \\
\text { tăng } \\
\text { 'lie' }\end{array}$ & $\begin{array}{c}\text { 爬 } \\
\text { pá } \\
\text { 'crawl' }\end{array}$ & $\begin{array}{c}\text { 蹲 } \\
\text { dūn } \\
\text { 'squat' }\end{array}$ & $\begin{array}{c}\text { 踠 } \\
\text { gui } \\
\text { 'kneel' }\end{array}$ & $\begin{array}{c}\text { 漂 } \\
\text { piāo } \\
\text { 'float' }\end{array}$ \\
\hline \multicolumn{2}{|l|}{ Pre-V } & 43 & 8 & 1 & $\varnothing$ & $\varnothing$ & 1 & $\varnothing$ & 1 \\
\hline \multirow[t]{2}{*}{$\begin{array}{l}\text { Post- } \\
\text { V }\end{array}$} & $\begin{array}{l}\text { first } \\
V\end{array}$ & $\varnothing$ & 14 & 8 & 2 & 3 & $\varnothing$ & $\varnothing$ & $\varnothing$ \\
\hline & $\begin{array}{l}\text { main } \\
\text { verb }\end{array}$ & 67 & 9 & 3 & 1 & $\varnothing$ & 1 & 1 & $\varnothing$ \\
\hline \multicolumn{2}{|l|}{ Total } & 110 & 31 & 12 & 3 & 3 & 2 & 1 & 1 \\
\hline
\end{tabular}


The paradox of the construction [V zai $\left.\mathrm{NP}_{\mathrm{Loc}}\right]$... / CLAO 34(2005) 169-220

The following two sentences illustrate the use of the verbs zhàn 'stand' and $z u o$ 'sit' as the first verb in a serial verb construction.

$$
\begin{array}{llllll}
\text { 过 } & \text { 了 } & \text { 两 } & \text { 天, 这 俩 } & \text { 老头儿 } & \text { 又 } \\
\text { Guò le } & \text { liăng tiān, zhè liá } & \text { lăotóur } & \text { yòu }
\end{array}
$$
cross CRS two day this two.item old.gentleman again

来了就站 那门脸儿 那儿看着。 lái le jiu zhàn nèi ménliăr nàr kàn zhe. come CRS just stand that door.face there look DUR 'Two days later, these two old gentlemen came again, and stood there in the doorway looking around.'

In example (36), the speaker talks about Manchu rituals.

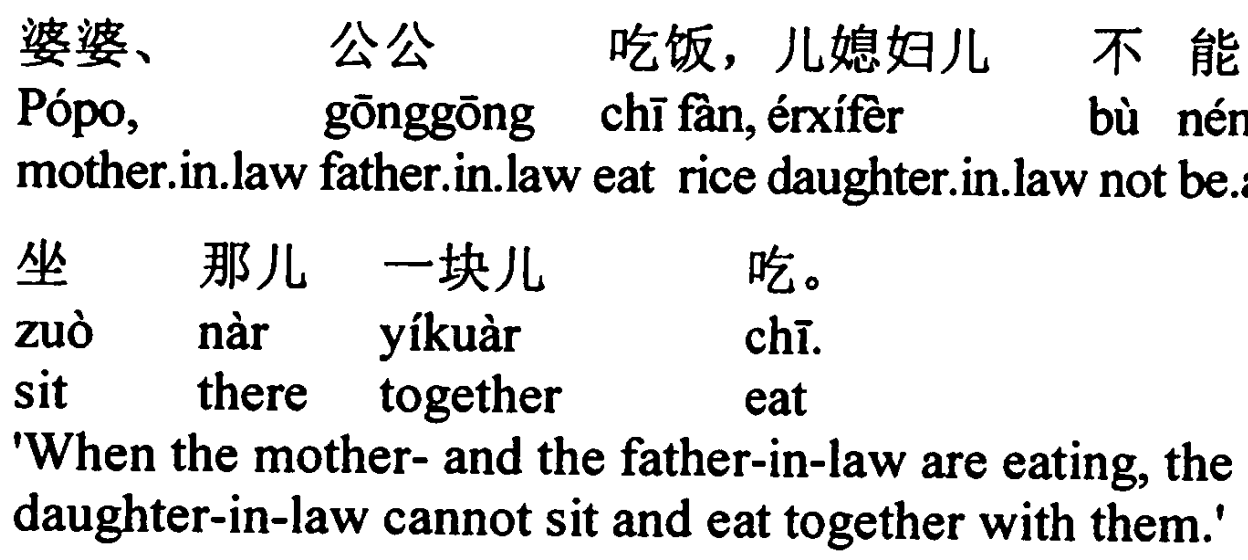

We suggest that the position of the locative phrase (preverbal and postverbal) with the first verb in a series in the Beijing dialect of Mandarin can potentially differentiate between the terminative and the durative meaning, just like the particles le or zhe do. However, due to the tendency to see the first verb in a series as denoting a background or durative event for verbs of posture, the postverbal locative phrase with such a verb is accordingly easily interpreted as expressing the durative meaning. Thus, the original distinction is blurred in this particular syntactic environment. For this reason, we do not assess the correlation between construction position and meaning for intransitive verbs used as first in a V-V series. Frequency 
Chirkova K. \& Lamarre C. / Cahiers de Linguistique-Asie Orientale 34(2005) 169-220

of co-occurrence of intransitive verbs as first in a V-V series with de, $z a i$, and the zero form is presented in Table 5. Intransitive verbs normally do not co-occur with dao in the corpus, for which reason dao is not included in the table. In this as well as in the following tables, "I" stands for older language consultants, and "II" for younger language consultants.

Table 5. Distribution of de, zai and the zero form with verbs of posture as first $\mathrm{V}$ in a $\mathrm{V}-\mathrm{V}$ series

\begin{tabular}{|c|c|c|c|c|c|c|}
\hline \multirow{2}{*}{$\begin{array}{l}\text { Form } \\
\text { introducing } \\
N_{\text {LOC }}\end{array}$} & \multicolumn{2}{|c|}{$\begin{array}{l}\text { 坐 zuò } \\
\text { 'sit' }\end{array}$} & \multirow{2}{*}{$\begin{array}{c}\begin{array}{c}\text { 站 zhàn } \\
\text { 'stand' }\end{array} \\
\text { I }\end{array}$} & \multirow{2}{*}{$\begin{array}{c}\begin{array}{c}\mathbb{e} 巴 \boldsymbol{p} a ́ \\
\text { 'crawl' }\end{array} \\
\mathbf{I}\end{array}$} & \multicolumn{2}{|c|}{$\begin{array}{c}\text { 躺 tăng } \\
\text { 'lie' }\end{array}$} \\
\hline & I & II & & & I & II \\
\hline 的 $d e$ & 8 & $\varnothing$ & 2 & $\varnothing$ & $\varnothing$ & $\varnothing$ \\
\hline 在 $z a i$ & 2 & 3 & 5 & 1 & $\varnothing$ & 1 \\
\hline zero form & 1 & $\varnothing$ & 1 & 2 & 1 & $\varnothing$ \\
\hline Total & 11 & 3 & 8 & 3 & 1 & 1 \\
\hline
\end{tabular}

Note that few exceptions to the otherwise strict correspondence of construction position and meaning (postverbal - terminative) in Guānhuà zhìnán are found precisely in this syntactic environment, i.e. with the verb followed by a locative phrase occurring as the first in a serial verb construction:

小弟

Xiăodi

little.brother precisely sit 'I was just sitting inside drinking tea.' zhèng zuò zai wūli
正坐 在 屋哀

喝茶了。 hē chá le. ${ }^{15}$ drink tea RLV (vol. II, ch. 35, p. 39a)

\footnotetext{
${ }^{15}$ The modal sentence final particle $了$ le in Guänhuà zhĭnán corresponds to the Modern Mandarin sentence final particle 呢 ne, and has been glossed here accordingly.
} 
The paradox of the construction $\left[\mathrm{V}\right.$ zai $\left.\mathrm{NP}_{\mathrm{Loc}}\right] \ldots /$ / CLAO 34(2005) 169-220

2.4.3. Correlation between construction position and meaning for intransitive verbs used as the main verb

Table 6 presents the correlation between construction position and meaning for intransitive verbs used as the main verb. The verb $z h \grave{u}$ 'live' has been excluded, as already outlined with regard to Table 4 .

Table 6. Correlation between position and meaning for intransitive verbs used as the main verb

\begin{tabular}{|c|c|c|c|c|c|c|c|c|}
\hline Verb & \multicolumn{2}{|c|}{ 坐 zuò 'sit' } & \multicolumn{2}{|c|}{ 站 zhàn 'stand' } & \multirow{2}{*}{$\begin{array}{c}\begin{array}{c}\text { 躺 } \\
\text { tăng } \\
\text { 'lie' }\end{array} \\
\mathrm{I}\end{array}$} & \multirow{2}{*}{$\begin{array}{c}\begin{array}{c}\text { 蹲 } \\
\text { dūn } \\
\text { 'squat' }\end{array} \\
\text { I }\end{array}$} & \multirow{2}{*}{$\begin{array}{c}\begin{array}{c}\text { 踭 guì } \\
\text { 'kneel' }\end{array} \\
\text { I }\end{array}$} & \multirow{2}{*}{$\begin{array}{c}\begin{array}{c}\text { 漂 piāo } \\
\text { 'float' }\end{array} \\
\text { II }\end{array}$} \\
\hline $\begin{array}{l}\text { Form } \\
\text { introdu- } \\
\text { cing } \\
\mathrm{NP}_{\text {LoC }} \\
\end{array}$ & I & II & I & II & & & & \\
\hline 的 de & $\begin{array}{c}1 \\
{[100 \%]}\end{array}$ & $\begin{array}{c}1 \\
{[100 \%]}\end{array}$ & $\varnothing$ & $\varnothing$ & $\varnothing$ & $\varnothing$ & $\varnothing$ & $\begin{array}{c}1 \\
{[100 \%]}\end{array}$ \\
\hline 在 $z a i$ & $\varnothing$ & $\varnothing$ & $\begin{array}{c}2 \\
{[50 \%]}\end{array}$ & $\varnothing$ & $\begin{array}{c}1 \\
{[100 \%]}\end{array}$ & $\varnothing$ & $\begin{array}{c}1 \\
{[100 \%]}\end{array}$ & $\varnothing$ \\
\hline $\begin{array}{l}\text { zero } \\
\text { form }\end{array}$ & $\begin{array}{c}5 \\
{[100 \%]}\end{array}$ & $\begin{array}{c}2 \\
{[100 \%]}\end{array}$ & $\varnothing$ & $\begin{array}{c}1 \\
{[100 \%]}\end{array}$ & $\varnothing$ & $\begin{array}{c}1 \\
{[\varnothing \%]}\end{array}$ & $\varnothing$ & $\varnothing$ \\
\hline Total & 6 & 3 & 2 & 1 & 1 & 1 & 1 & 1 \\
\hline
\end{tabular}

When posture verbs used as the main verb are preceded by a locative phrase, they are usually followed by the durative particle zhe, e.g. example (38):

$\begin{array}{llllll}\text { 小孩儿反正 } & \text { 在 } & \text { 这儿 坐 } & \text { 着, } & \text { 我们 } \\ \text { Xiǎohár fänzhèng } & \text { zài } & \text { zhèr } & \text { zuò } & \text { zhe, } & \text { wormen } \\ \text { child in.any.case be.in } & \text { here sit } & \text { DUR } & 1 P\end{array}$

在 那儿 唱 戏 玩儿。

zài nàr chàng xì wár.

be.in there sing opera have.fun

'The children were sitting with us here anyway, so we had our fun singing Beijing opera.' 
Chirkova K. \& Lamarre C. / Cahiers de Linguistique - Asie Orientale 34(2005) 169-220

If, on the other hand, the locative phrase accompanying a verb of posture used as the main verb is postverbal, the sentence expresses either a change of location, as in example (39), or a durative situation, as in example (40). In sentence (39), the speaker recalls that after dog taxes were introduced in Beijing in the 1990s, many people tried to get rid of their pets, sometimes giving them to the relatives in the countryside or sometimes simply abandoning them. $\mathrm{He}$ also remembers, his two friends ate the dog that used to be somebody's pet. Dog meat is a delicacy in China.

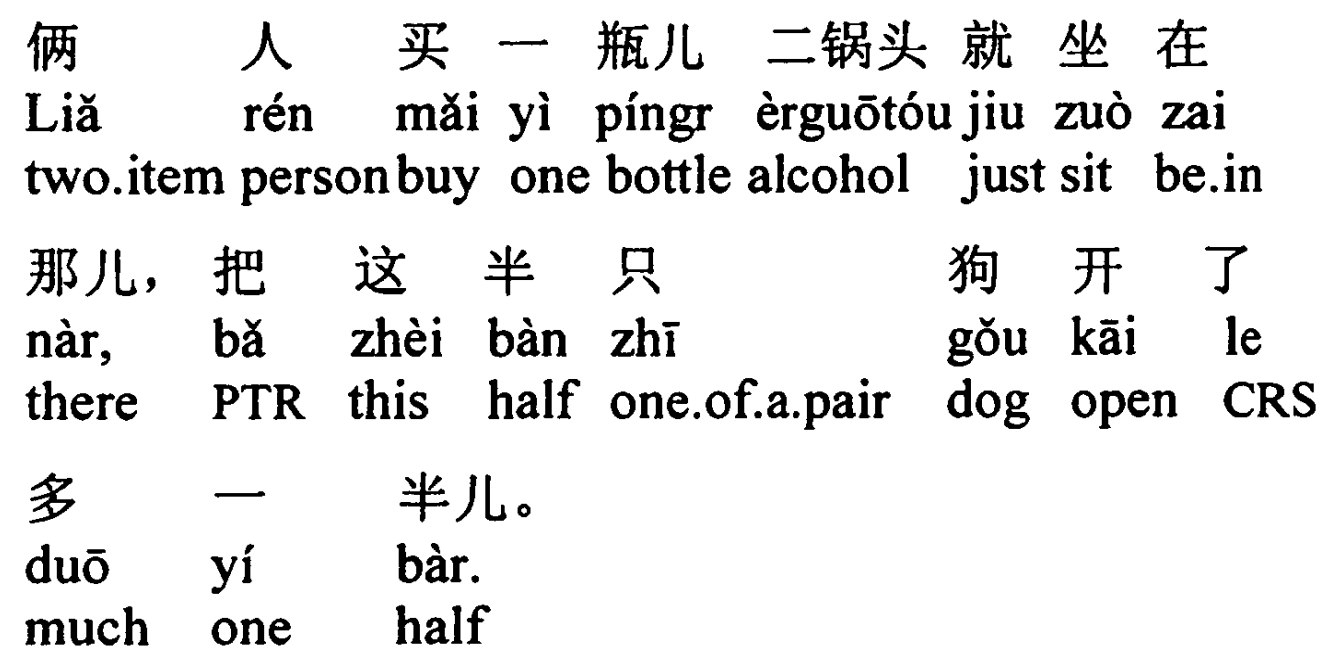

'So the two people bought a bottle of sorghum vodka, sat down there and ate more than half of the dog.'

Sentence (40) is taken from a fairy tale about two stone lions that used to turn into demons.

（40）白天 就 蹲 那儿, 到 晚上 就成精了。 Báitian jiu dūn nàr, dào wănshang jiu chéngjīng le. daytime just squat there arrive evening just become.demon CRS 'In the daytime, they were just squatting there, but in the evening they turned into demons.' 
The paradox of the construction $\left[\mathrm{V}\right.$ zai $\left.\mathrm{NP}_{\mathrm{LOC}}\right] \ldots /$ / CLAO 34(2005) 169-220

\subsubsection{Summary}

(a) The use of the verb $z h \grave{u}$ 'live' in the corpus differs markedly from that reflected in Guānhuà zhĭnán, Xiăo É and Yànjīng füy̆u. The initial distinction between the two meanings of this verb, i.e. having residence and taking up one's residence, typical for these texts and initially differentiated by the position of the accompanying locative phrase (preverbal for the situation of having residence and postverbal for the event of taking up one's residence), is gradually obscured in the Beijing dialect of Mandarin from older to younger language consultants.

(b) Intransitive verbs followed by a locative phrase are used mostly as the first verbal phrase in a serial verb construction.

(c) When intransitive verbs are used as the main verb in the sentence, construction meaning and position mostly match.

2.5. Transitive verbs: correlation between construction position and meaning

\subsubsection{Ge 'put' and fang 'put'}

The Beijing dialect of Mandarin has two verbs expressing the meaning 'put, place', ge $\bar{e}$ and fang. Of these verbs, ge means only 'put, place', whereas fang has, in addition to 'put', several other meanings, i.e. 'let go', 'loosen', 'dissipate', and 'indulge'. Gē is also more typical for the spoken language, whereas fang is normally used in the meaning 'put' in the written language.

In the corpus, there is an interesting correlation between the age of language consultants and the frequency of the use of $g \bar{e}$. Older language consultants use $g \bar{e}$ predominantly (55 times) and fang rarely (10 times). Younger language consultants, on the other hand, use ge and fang equally ( 7 times each verb). It is also worthy of note that while ge normally co-occurs with a variety of forms, fang is predominantly followed by zai. It is reasonable to conclude 
Chirkova K. \& Lamarre C. / Cahiers de Linguistique - Asie Orientale 34(2005) 169-220

that having borrowed fang for 'put' from the written language, the Beijing dialect of Mandarin has also imported with it the coverb zai. The distribution of $g \bar{e}$ and fang in the speech of older and younger language consultants is summarized in the following table.

Table 7. Correlation between construction position and meaning for 㨄 $g \bar{e}$ 'put' and 放 fang 'put'

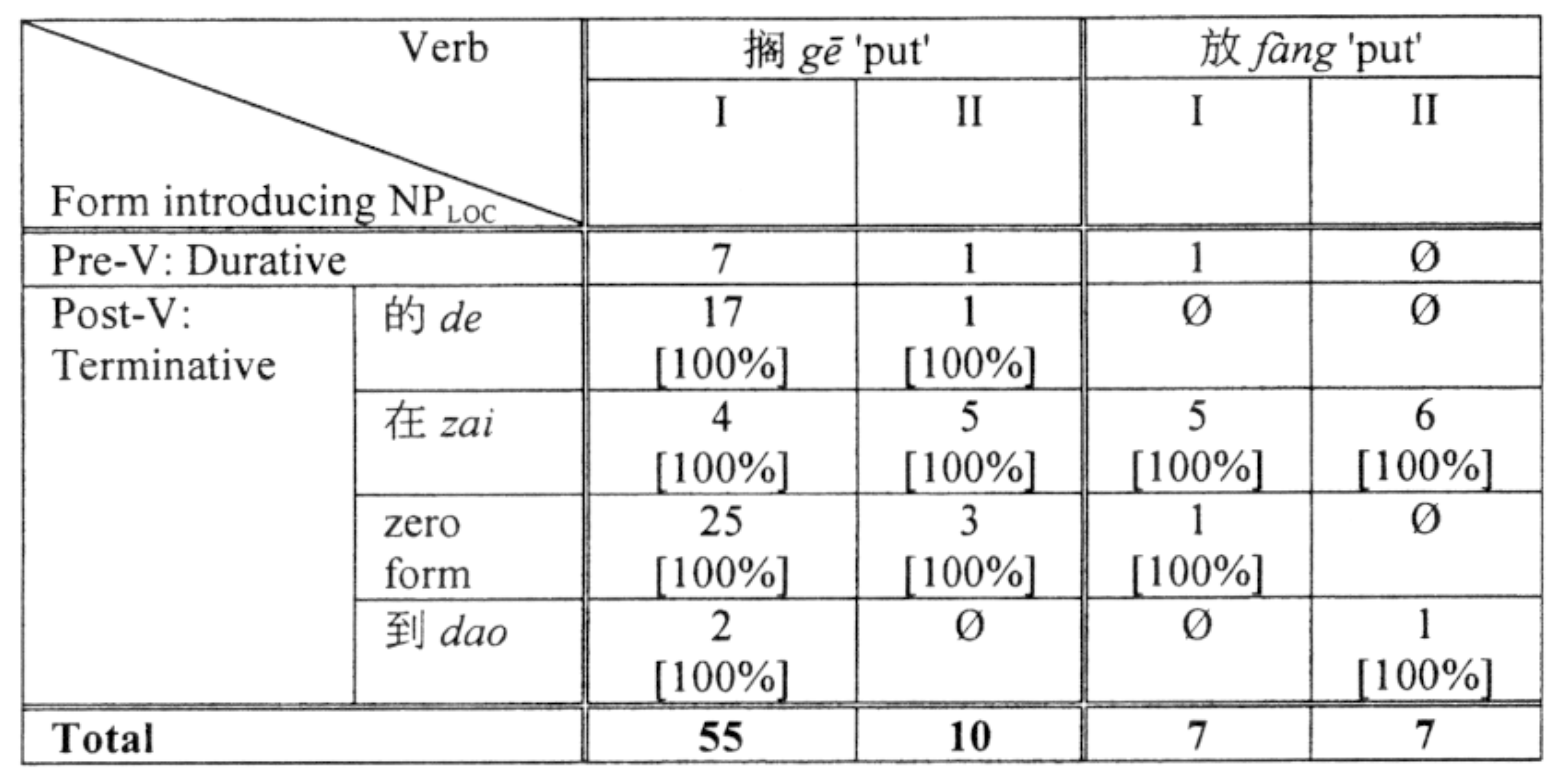

Example (41) illustrates the use of $g \bar{e}$ in a sentence with a preverbal locative phrase. The language consultant speaks about a bicycle tax sticker, which has to be pasted on the bicycle.

$$
\begin{aligned}
& \text { 我都忘了贴, 忘了 往 } \\
& \text { Wǒ dōu wàng le tiē, wàng le wàng } \\
& \text { is all forget CRS paste forget CRS towards } \\
& \text { 自行车上贴, 就 老 跟 淣儿 } \\
& \text { zìxíngchē shang tiē, jiu lăo gēn dōur } \\
& \text { bicycle up paste just all.the.time follow pocket }
\end{aligned}
$$


The paradox of the construction [V zai $\left.\mathrm{NP}_{\mathrm{LOC}}\right]$... / CLAO 34(2005) 169-220

里 搁 着。
li ge zhe.
inside put DUR
'I completely forgot to stick it, forgot to stick it onto the
bicycle and was carrying it around all the time in my
pocket.'

In the following sentences, the verb ge 'put' is accompanied by the postverbal locative phrase. All examples express a change of location. The locative phrase is introduced in examples (42) and (43) by the zero form and in example (44) by the form de.

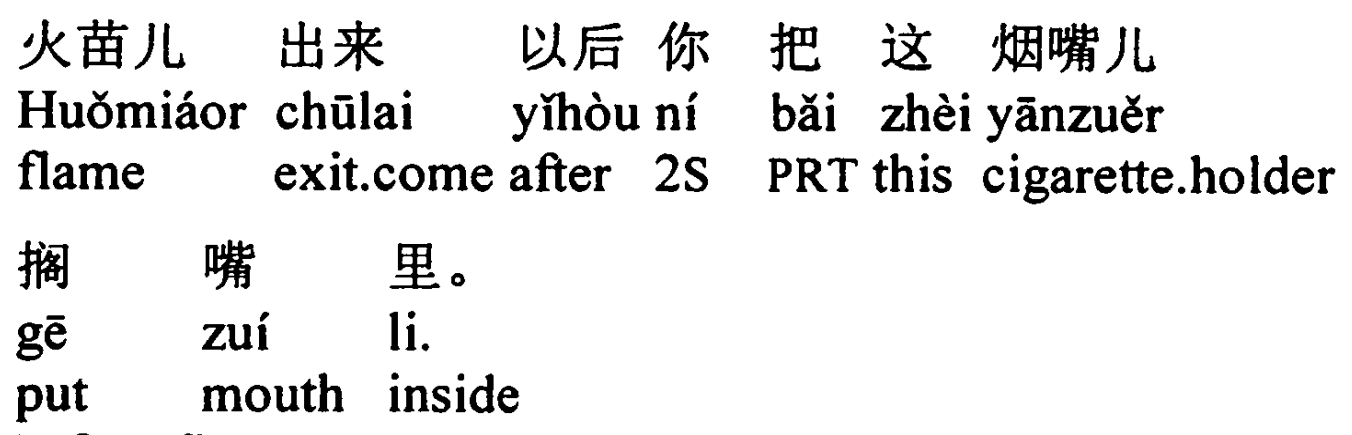

'After flames come out, put the cigarette holder into the mouth.'

In the following sentence, the speaker recalls how he used to buy sugarcoated haws in his childhood.

$$
\text { 得, 你买个一毛五分的, 给 }
$$

Dé, ní măi ge yì máo wŭ fèn de, gěi reach $2 S$ buy item one ten.cent five cent SUB give 您一大块, 把那东西 搁里去。 nín yí dà kuài, bă nèi dōngxi gē lì qu. 2S.HON one big piece PTR that thing put inside go 'Well, you bought a piece for 15 cents, they gave you a huge lump and you put it inside.' 
Chirkova K. \& Lamarre C. / Cahiers de Linguistique - Asie Orientale 34(2005) 169-220

In example (44), the language consultant explains how singers of Beijing opera make themselves up before a performance. They brush the hair to the back and cover it with a cloth, so that the make-up does not accidentally make their hair dirty.

（44）他把这个 头发弄的后边儿去,

Tā băi zhèi ge tóufa nòng de hòubiar qu, 3 PTR this item hair make de back.side go 把这布搁的这儿哈儿。 băi zhèi bù gē de zhèrher. PTR this cloth put de here 'He combed the hair to the back and placed the cloth here.'

For more examples with the verbs gē 'put' and fang 'put', see also sentences (13), (16), (18), (19), (23) and (24).

2.5.2. Correlation between construction position and meaning for transitive verbs

Tables 8 and 9 illustrate the correlation between construction position and meaning for the eleven transitive verbs selected for analysis. 


\begin{tabular}{|c|c|c|c|c|c|c|c|c|c|c|}
\hline \multirow{2}{*}{\multicolumn{2}{|c|}{ Position }} & \multicolumn{2}{|c|}{ 挂 guà 'hang' } & \multicolumn{2}{|c|}{ 埋 mái 'bury' } & \multicolumn{2}{|c|}{ 扔 rēng 'toss' } & \multicolumn{2}{|c|}{ 停 ting 'stop' } & \multirow{2}{*}{$\begin{array}{c}\begin{array}{c}\text { 写 } x i e ̌ ~ \\
\text { 'write' }\end{array} \\
\text { I }\end{array}$} \\
\hline & & I & II & I & II & I & II & I & II & \\
\hline \multicolumn{2}{|c|}{ Pre-V: Durative } & 3 & $\varnothing$ & $\varnothing$ & $\varnothing$ & $\varnothing$ & $\varnothing$ & 1 & $\varnothing$ & $\varnothing$ \\
\hline \multirow{4}{*}{$\begin{array}{l}\text { Post-V: } \\
\text { Termi- } \\
\text { native }\end{array}$} & 的 de & $\begin{array}{c}5 \\
{[100 \%]}\end{array}$ & $\varnothing$ & $\begin{array}{c}2 \\
{[100 \%]}\end{array}$ & $\begin{array}{c}3 \\
{[100 \%]}\end{array}$ & $\begin{array}{c}1 \\
{[100 \%]}\end{array}$ & $\varnothing$ & $\begin{array}{c}1 \\
{[100 \%]}\end{array}$ & $\begin{array}{c}1 \\
{[100 \%]}\end{array}$ & $\begin{array}{c}1 \\
{[100 \%]}\end{array}$ \\
\hline & 在 $z a i$ & $\begin{array}{c}2 \\
{[50 \%]}\end{array}$ & $\varnothing$ & $\begin{array}{c}1 \\
{[100 \%]}\end{array}$ & $\begin{array}{c}2 \\
{[100 \%]}\end{array}$ & $\varnothing$ & $\varnothing$ & $\varnothing$ & $\begin{array}{c}1 \\
{[100 \%]}\end{array}$ & $\varnothing$ \\
\hline & $\begin{array}{l}\text { zero } \\
\text { form }\end{array}$ & $\varnothing$ & $\begin{array}{c}1 \\
{[100 \%]}\end{array}$ & $\varnothing$ & $\begin{array}{c}1 \\
{[100 \%]}\end{array}$ & $\begin{array}{c}1 \\
{[100 \%}\end{array}$ & $\begin{array}{c}1 \\
{[100 \%]}\end{array}$ & $\varnothing$ & $\varnothing$ & $\begin{array}{c}2 \\
{[100 \%]}\end{array}$ \\
\hline & 到 $d a o$ & $\varnothing$ & $\varnothing$ & $\varnothing$ & $\varnothing$ & $\varnothing$ & $\begin{array}{c}1 \\
{[100 \%]} \\
\end{array}$ & $\varnothing$ & $\varnothing$ & $\begin{array}{c}1 \\
{[100 \%]} \\
\end{array}$ \\
\hline \multicolumn{2}{|l|}{ Total } & 10 & 1 & 3 & 6 & 2 & 2 & 2 & 2 & 4 \\
\hline
\end{tabular}

Table 8. Correlation between construction position and meaning for 挂 guà 'hang', 埋 mái 'bury', 扔 rēng 'toss', 停 ting 'stop' and 写 $x i e ̌$ 'write' 
Chirkova K. \& Lamarre C. / Cahiers de Linguistique - Asie Orientale 34(2005) 169-220

Table 9. Correlation between construction position and meaning for 贴 $t i \bar{e}$ 'stick', 装 zhuāng 'install', 摆 băi 'display', 堆 $d u \bar{l}$ 'pile up', 躲 duŏ 'hide' and 锁 suó 'lock'

\begin{tabular}{|c|c|c|c|c|c|c|c|c|c|}
\hline 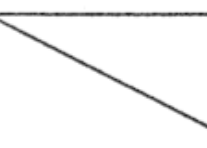 & Verb & $\begin{array}{l}\text { 贴 } t i \bar{e} \\
\text { 'stick' }\end{array}$ & $\begin{array}{c}\text { 装 } \\
\text { zhuāng } \\
\text { 'install' }\end{array}$ & & $\begin{array}{l}\text { băi } \\
\text { lay' }\end{array}$ & $\begin{array}{l}\text { 堆 } d \\
\text { 'pile }\end{array}$ & & $\begin{array}{c}\text { 躲 } \\
\text { duð } \\
\text { 'hide' }\end{array}$ & $\begin{array}{c}\text { 锁 } \\
\text { suð } \\
\text { 'lock' }\end{array}$ \\
\hline Position & & I & I & I & II & I & II & II & I \\
\hline Pre-V: Dur & & 1 & $\varnothing$ & $\varnothing$ & $\varnothing$ & $\varnothing$ & 1 & $\varnothing$ & 1 \\
\hline $\begin{array}{l}\text { Post-V: } \\
\text { Terminative }\end{array}$ & $\begin{array}{l}\text { 的 } \\
d e\end{array}$ & $\varnothing$ & $\begin{array}{c}1 \\
{[100 \%]}\end{array}$ & $\varnothing$ & $\varnothing$ & $\begin{array}{c}1 \\
{[100 \%]}\end{array}$ & $\varnothing$ & $\varnothing$ & $\varnothing$ \\
\hline & $\begin{array}{l}\text { 在 } \\
z a i\end{array}$ & $\varnothing$ & $\begin{array}{c}1 \\
{[100 \%]}\end{array}$ & $\begin{array}{c}1 \\
{[\emptyset \%]}\end{array}$ & $\begin{array}{c}1 \\
{[100 \%]}\end{array}$ & $\varnothing$ & $\varnothing$ & $\begin{array}{c}1 \\
{[100 \%]}\end{array}$ & $\varnothing$ \\
\hline & $\begin{array}{l}\text { zero } \\
\text { form }\end{array}$ & $\begin{array}{c}2 \\
{[100 \%]}\end{array}$ & $\begin{array}{c}1 \\
{[100 \%]}\end{array}$ & $\theta$ & $\varnothing$ & $\varnothing$ & $\varnothing$ & $\varnothing$ & $\varnothing$ \\
\hline & $\begin{array}{l}\text { 到 } \\
\text { dao }\end{array}$ & $\varnothing$ & $\varnothing$ & $\varnothing$ & $\varnothing$ & $\varnothing$ & $\varnothing$ & $\theta$ & $\varnothing$ \\
\hline Total & & 3 & 3 & 1 & 1 & 1 & 1 & 1 & 1 \\
\hline
\end{tabular}

The verb guà 'hang' in example (45) is used to denote a terminative meaning, whereas in example (46), the same verb expresses a durative meaning. In sentence (45), the speaker talks about a fight between Muslim and non-Muslim Chinese in Beijing. In order to tease and provoke Muslims, a Chinese butcher hung up a pig's head in a mosque.

卖肉的 人 呢找来 不少 人,
Mài ròu de rén ne zhăo lai bù shăo rén,
sell meat SUB person RLV look.for come not few person

拿 那个 猪头挂 的清真寺 去了。

ná nèi ge zhūtóu guà de Qīngzhēnsì qu le.

take that item pig.head hang de mosque go CRS

'The butchers assembled a lot of people, took the pig's head and hung it in the mosque.'

In sentence (46), the language consultant describes the appearance of water peddlers in Beijing. 
The paradox of the construction $\left[\mathrm{V}\right.$ zai $\left.\mathrm{NP}_{\mathrm{LOC}}\right] \ldots /$ / CLAO 34(2005) 169-220

(46)

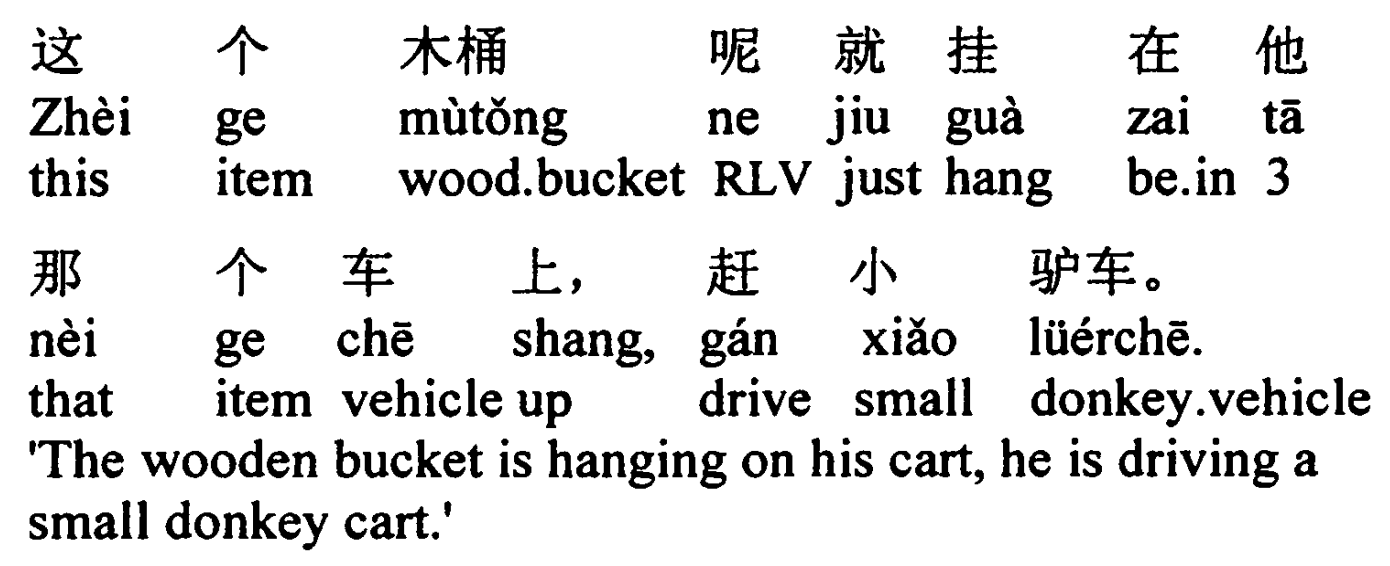

The next example illustrates the use of the verb suó 'to lock' with a preverbal locative phrase. In this sentence, the language consultant speaks about his family treasures, which got lost in the years of the Cultural Revolution.

\begin{tabular}{|c|c|c|c|c|c|}
\hline \multirow{2}{*}{$\begin{array}{l}\text { 到 } \\
\text { Dào } \\
\text { arrive } \\
\text { 还 } \\
\text { hái } \\
\text { still }\end{array}$} & $\begin{array}{l}\text { 文化 大 } \\
\text { wénhuà dà } \\
\text { culture big }\end{array}$ & \multicolumn{2}{|c|}{$\begin{array}{l}\text { 革命 的 } \\
\text { géming de } \\
\text { revolution }\end{array}$} & \multicolumn{2}{|c|}{$\begin{array}{l}\text { 时候儿, } \\
\text { shíhour }\end{array}$} \\
\hline & $\begin{array}{ll}\text { 看见 } & \text { 过 } \\
\text { kànjian } & \text { guo } \\
\text { look.see } & \text { EXP }\end{array}$ & $\begin{array}{l}\text { 那 } \\
\text { nèi } \\
\text { that }\end{array}$ & $\begin{array}{l}\text { 东西, } \\
\text { dōngxi, } \\
\text { thing }\end{array}$ & $\begin{array}{l}\text { 还 } \\
\text { hái } \\
\text { still }\end{array}$ & $\begin{array}{l}\text { 在 } \\
\text { zài } \\
\text { be.in }\end{array}$ \\
\hline $\begin{array}{l}\text { 那 } \\
\text { nèi } \\
\text { that }\end{array}$ & $\begin{array}{l}\text { 屋子 } \\
\text { wūzi } \\
\text { room }\end{array}$ & $\begin{array}{l}\text { 锁 } \\
\text { suǒ } \\
\text { lock }\end{array}$ & $\begin{array}{l}\text { 着 } \\
\text { zhe } \\
\text { DUR }\end{array}$ & $\begin{array}{l}\text { 呢。 } \\
\text { ne. } \\
\text { RLV }\end{array}$ & \\
\hline
\end{tabular}

2.6. Summary for all verbs selected for analysis

Overall in the corpus, both transitive and intransitive verbs occurring as the main verb have the terminative meaning when followed by a locative phrase, apart from some rare exceptions.

Below, we give a summary of Tables $3,6,7,8$ and 9 to give a global account of the percentages of all sentences for which construction position (postverbal) and construction meaning (terminative) do not match. 
Chirkova K. \& Lamarre C. / Cahiers de Linguistique - Asie Orientale 34(2005) 169-220

a) For the verb zhù 'live, take up residence', approximately $57 \%$ sentences with the postverbal locative phrase (38 out of the total of 67 examples) have a durative meaning, i.e. we can speak of the mismatch of construction position and meaning.

(b) For other intransitive verbs of posture, when used as the main verb, in $12.5 \%$ of all cases ( 2 sentences out of the total of 16 ) construction position and meaning do not match.

(c) For transitive verbs (of placement), only approximately $1.9 \%$ (2 out of the total of 107 sentences) are durative.

These statistics clearly show the semantic change which the verb $z h \grave{u}$ has undergone from two distinct but related meanings, i.e. terminative 'take up one's residence' and durative 'live', to one, mostly durative, 'live'. On the whole, construction position and meaning match for all other verbs discussed in this article.

We note that the mismatch between construction position and meaning, i.e. the durative reading for the postverbal locative phrase, is more frequent with intransitive posture verbs $(12.5 \%$ or 2 cases out of the total of 16 sentences) rather than with transitive verbs of placement (1.9\% or 2 cases out of 107 sentences).

It is also notable that the mismatch of construction position and meaning occurs in three out of four cases (i.e. with zhàn 'stand', guà 'hang' and băi 'display') when the postverbal locative phrase is introduced by $z a i$, i.e. the form that is arguably alien to the Beijing dialect of Mandarin in the postverbal position. Hence, importing zai as a postverbal locative coverb from Standard Mandarin, the Beijing dialect of Mandarin borrows with it the ambiguity of the written language with regard to the aspectual interpretation of postverbal locative phrases.

\section{CONCLUSIONS}

3.1. Distribution of de, zai, dao, and the zero form in the corpus

All forms, i.e. de, zai, the zero form and dao, have been attested in the corpus as means to introduce postverbal locative 
The paradox of the construction $\left[\mathrm{V} z a i \mathrm{NP}_{\mathrm{LOC}}\right]$... / CLAO 34(2005) 169-220

phrases. The following features are characteristic for their use in the corpus:

(a) The rate of postverbal occurrences of $z a i$ is low for all age groups.

(b) Preferred ways to introduce postverbal locative phrases for older speakers are de or the zero form.

(c) The postverbal use of zài increases in the speech of younger speakers, whereas the use of $d e$ in their speech decreases.

(d) Dao is infrequent.

(e) One and the same speaker can use both zai and de to introduce postverbal locative phrases. There is therefore no evidence that $z a i$ automatically transforms into the form de in the spoken language, as suggested by Guō (1986).

We note that only a detailed survey of different forms, used to introduce postverbal locative phrases, in a variety of Northern dialects can shed more light on the part played by the autonomous meaning of these forms in determining the terminative or durative meaning of the entire construction. In the case of our Beijing Mandarin data, sentences with postverbal locative phrases introduced by zai show a considerably stronger tendency to denote the durative meaning than sentences with postverbal locative phrases introduced by the form de or the zero form. More precisely, as much as $25 \%$ (5 sentences out of 34) of all sentences with the postverbal zai are durative, versus only $2 \%$ ( 1 sentence out of 47 ) of sentences with the zero form and $0 \%$ (a total of 37 sentences) of sentences with the form de. These figures account for both transitive and intransitive verbs, but not for the verb zhù 'live', which is likely to reflect the semantic shift of an individual lexical item.

3.2. Correlation between construction position and meaning

Our main conclusion is that for the set of verbs considered the distinction between the durative meaning for preverbal locative 
Chirkova K. \& Lamarre C. / Cahiers de Linguistique-Asie Orientale 34(2005) 169-220

constructions and the terminative meaning for postverbal locative constructions is still typical for the Beijing dialect of Mandarin. Modern Beijing data by and large shows uniformity with the northern pattern, as described by Lamarre (2003a, 2003b, 2003c).

Written norms are however noticeable in the spoken language, as seen in the use of the verb zhù 'live', the verb fang 'put, place', and the postverbal locative coverb zai. The ambiguity of Standard Mandarin with respect to both terminative (change of location) and durative (the state resulting from a change of location) interpretations for the postverbal locative phrase enters the spoken language from the side of intransitive verbs, which occur frequently as the first verbal phrase in a serial verb construction.

Apart from the role played by the frequent use of verbs of posture in backgrounding clauses, we suggest that another possible explanation for this discrepancy between transitive and intransitive verbs may lie in the voice shift observed in sentences with transitive verbs when they have the durative meaning. For instance, the active sentence (Bă) ròu gē zai zhuōzi shang! 'Put the meat on the table!', where the word rou 'meat' is the patient and the object of the verb $g \bar{e}$ 'put', is terminative. In contrast, the semantically passive example (4), Zhūròu hái gē zai zhuōzi shang 'The meat was still lying on the table., where the word ròu 'meat' is the subject, is durative. ${ }^{16}$

The evolution from terminative to durative can and often is internally motivated, as is the case in Wú dialects. However, based on the fact the $\left[\mathrm{V} z a i \mathrm{NP}_{\mathrm{LOC}}\right]$ construction is never durative in Northern Mandarin dialects and appears not to have been either in early Beijing Mandarin, it is reasonable to conclude that the cooccurrence of both terminative and durative meaning for the postverbal locative phrase in Standard Mandarin is the result of influence from Central and Southern dialects on the written language. A similar influence has been noted in the case of the

${ }^{16}$ Lamarre thanks Hideki Kimura for his insightful comments on this issue. 
The paradox of the construction $\left[\mathrm{V} z a i \mathrm{NP}_{\mathrm{Loc}}\right] \ldots /$ / CLAO 34(2005) 169-220

preverbal progressive zài (see Jaxontov Chinese edition 1958:151-2, Chirkova 2003:27 and Lamarre 2003c for details).

As noted by Smith (1991: 40), "[v]erbs of posture and location can often appear in both stative and non-stative sentences. As statives they focus on a position or posture; as non-statives they focus on earlier stages of the causal chain." The derived durative meaning of the [ $\mathrm{V}$ zai $\left.\mathrm{NP}_{\text {Loc }}\right]$ construction thus finds a natural, probably cross-linguistically valid, motivation in the semantics of these verbs, cf. Smith's analysis of the verb hang 'hang' in English followed by a locative phrase. However, this semantically motivated derivation is not observed in Northern Mandarin dialects, which favor the consistency of the correlation between the postverbal positioning of the locative phrase, the meaning of change of location and the terminative meaning of the sentence. In other words, in Northern dialects, the weight of the construction meaning wins.

\section{REFERENCES}

CHAO Yuen Ren 赵元任 (1968). A grammar of spoken Chinese. Berkeley : University of California Press.

CHÉN Píng 陈平 (1988). Lùn Xiàndài Hànyŭ shijiàn xìtǒng de sānyuán jiégou 论现代汉语事件系统的三元结构 [On the tripartite structure of the temporal system of contemporary Chinese]. Zhōngguó yǔwén, 6, pp. 401-422.

CHIRKOVA Ekaterina (2003). In search of time in Peking Mandarin. Leiden : CNWS Publications.

COMRIE Bernard (1976). Aspect. Cambridge : Cambridge University Press.

DRAGUNOV Aleksandr AleksandroviC (1952). Issledovanija po grammatike sovremennogo kitajskogo jazyka [Studies in modern Chinese grammar]. Moscow : Akademija Nauk. 
Chirkova K. \& Lamarre C. / Cahiers de Linguistique - Asie Orientale 34(2005) 169-220

FÀN Jìyān 范继淹 (1982). 论介词短语 “在+处所' Lùn jiècí duányŭ 'zai + chúsuó' [On the prepositional phrase "zai + location"]. Yüyán yánjiū, 1, pp. 71-87.

GILES Herbert Allen (1912). A Chinese-English dictionary. Shanghai : Kerry and Walsh, London : Bernard Quaritch. Second edition, revised and enlarged. First published in 1892.

GOLDBERG Adele \& Ray JACKENDOFF (2004). The English Resultative as a family of constructions. Language, 80(3), pp. 534-568.

GUO Liángfū 郭良大, editor-in-chief (2000). Yingyòng Hànyǔ cídiăn 应 用汉语词典 [Applied dictionary of Chinese]. Beijing : Shāngwù Yìnshūguăn.

GUŌ Xī 郭熙 (1986). Fàng dao zhuōzi shang, fâng zai zhuōzi shang, fâng zhuōzi shang 放到桌子上, 放在桌子上, 放桌子上 [On fang dao zhuōzi shang 'put on the table', fâng zai zhuözi shang 'put on the table', fang zhuōzi shang 'put on the table']. Zhöngguó yüwén, 1, pp. 20-23.

HOPPER Paul \& Sandra THOMPSON (1980). Transitivity in Grammar and Discourse. Language, 56(2), pp. 251-99.

HÚ Míngyáng 胡明扬 (1991). Bexijīnghuà méi yơu zài zì 北京话没有 '在' 字 [Beijing Mandarin does not have the word zài 'be in']. Yüyán jiànshè, 9, pp. 42.

JAXONTOV Sergej Evgen'evix (1957). Kategorija glagola v kitajskom jazyke [The verbal category in the Chinese language]. Leningrad : Izdatel'stvo Leningradskogo Universiteta.

(Chinese translation) YĂHÓNGTUOFŌ 雅洪托夫 (1958). Hànyŭ de dòngci fanchóu 汉语的动词范畴 [The verbal category in the Chinese language]. Beijing : Zhōnghuá Shūjú. 
The paradox of the construction $\left[\mathrm{V} z a i \mathrm{NP}_{\mathrm{LOC}}\right] \ldots$ / CLAO 34(2005) 169-220

JIĀNG Lánshēng 江蓝生 (1994). 'Dòngcí + X + dìdiăncí' jùxíng zhōng jiècí de tànyuán '动词 $+\mathrm{X}+$ 地点词' 句型中介词 '的' 探源 [On the origin of the preposition de in the construction 'verb $+\mathrm{X}$ + locative']. Gŭ Hànyŭ yánjiū, 4, pp. 21-27, 20.

LAMARRE Christine (2003a). Jootai henka, koobun, sosite gengo kanshoo - chuugokugo no [V + zai + basho] koobun no keesu 状 態変化、構文、そして言語干涉：中国語の「 $\mathrm{V}+$ 在十場 所」構文のタース [Change of state, construction meaning and language interference: the case of Chinese [V zai L] construction]. Kaihen, 22, pp. 144-172.

LAMARRE Christine (2003b). Perfective and imperfective resultative in Chinese: the case of [V zài L] constructions. Paper presented at the Third Conference of the European Association of Chinese Linguistics (CEALC-3) in Ghent, 7-10 September 2003.

LAMARRE Christine (2003c). Cóng Héběi Jizhōu fāngyán duì xiàndài Hànyǔ [V zai L] géshì de zài tàntăo 从河北冀州方言对现代汉 语[V 在+处所词]格式的再探讨 [A new analysis of the modern Chinese [V zai L] construction based on the Jizhōu dialect data]. Dài, Zhàomíng 戴昭铭, editor in chief. 汉语方言语法研究和探 索. Hā’èrbīn : Hēilóngjiāng Rénmín Chūbănshè

LI Charles N. \& Sandra A. THOMPSON (1981). Mandarin Chinese: A functional reference grammar. Berkeley: University of California Press.

LIƯ Dānqīng 刘丹青 (2001). Fāngsữ tíyuán de ruògān lèixíngxué cānxiàng 方所题元的若干类型学参项 [Parameters related to the locative and spatial theta roles and typological variations]. Zhōngguó yưwén yánjiū, 1, pp. 11-23.

LIÚ Yuèhuá 刘月华, PĀN Wényú 潘文娱, GÙ Wexi 故 韦华. (1983). Shíyòng xiàndài Hànyŭ yúfă / Chinese grammar 实用现代汉语 语法. Beijing : Shāngwù Yìnshūguăn. 
218

Chirkova K. \& Lamarre C. / Cahiers de Linguistique - Asie Orientale 34(2005) 169-220

MULLIE Jozef Lodewijk Maria (1932). The structural principles of the Chinese language: An introduction to the spoken language (Northern Pekingese Dialect), vol. I. Translated from the Flemish by A. Omer Versichel. Peiping : The Bureau of Engraving and Printing.

NEDJALKOV Vladimir Petrovic \& Sergej Evgenjevic JAXONTOV (1988). The typology of resultative constructions. In : Nedjalkov, Vladimir PETROVIČ, ed. Typology of resultative constructions. Amsterdam : Benjamins. English translation by Bernard Comrie, pp. 3-62.

NORMAN Jerry (1988). Chinese. Cambridge : Cambridge University Press.

OOTA Tatsuo 太田辰夫 (1958). Chuugokugo rekishi bunpoo / A historical grammar of modern Chinese 中国語歴史文法. Tokyo : Koonan shoin.

(Chinese translation) TÀITIÁN Chénfū 太田辰夫 (1987). Zhōngguóyŭ lishĭ wénfă / A historical grammar of modern Chinese 《中国语 历史文法 Jiăng Shàoyŭ 蒋绍思 and Xú Chānghuá 许昌华, trans. Beijing : Běijīng Dàxué Chūbănshè.

PEYRAUBE Alain (1980). Les constructions locatives en chinois moderne. Hong Kong and Paris : Langages Croisés.

SMITH Carlota (1991). The parameter of aspect. Dordrecht : Kluwer Academic Publishers.

TAI James H.-Y. (1975). On the two functions of place adverbials in Mandarin Chinese. Journal of Chinese Linguistics, 3(2/3), pp. 154-180.

VERKUYL Henk Jacob (1993). A theory of aspectuality: The interaction between temporal and atemporal structure. Cambridge : Cambridge University Press. 
The paradox of the construction [V zai $\left.\mathrm{NP}_{\mathrm{Loc}}\right]$... / CLAO 34(2005) 169-220

WÁNG Huán 王还 (1957). Shuō 'zài 说 '在' [On zài]. Zhōngguó yǔwén, 2, pp. 55-26.

WÚ QYtài 吳啟太 \& ZHÈNG Yð̋ngbāng 鄭永邦 (1881). Guānhuà zhĭnán I $A$ guide to the Mandarin language 官話指南. Quoted from the 1989 reprint edition. Zhōu Chángxīng 周長星, ed. 1989. Yì băi nián qián de guóyŭ: Guānhuà zhinán一百年前的國語: 官話指 南 [Mandarin of one hundred years ago: A guide to the Mandarin language]. Taipei : Yìzhì Wénjù Túshū Gōngsī.

XÚ Dān 徐丹 (1994a). Sur zai/dao/de postverbal en pekinois. Cahiers de linguistique Asie Orientale, 23, pp. 333-348.

XÚ Dān (1994b). Guānyú Hànyŭ li 'dòngcí+X+dìdiănci' de jùxíng 关于汉 语里 '动词 $+\mathrm{X}+$ 地点词' 的句型 [On the Chinese construction 'verb + X+ locative phrase']. Zhöngguó yřwén, 3, pp. 180-185.

XÚ Lièjiơng 徐烈昫 \& SHÀO JìngmYn 邵敬敏 (1998). Shànghăi fāngyán yúfă yánjiū 上海语法研究 [Studies in Shànghăi grammar]. Shànghăi : Huádōng Shīfân Dàxué Chūbănshè.

YUÁN Yùlín 袁毓林 (2002). Fāngwèi jiècí zhe jí xiāngguān de yúfă xiànxiàng 方位介词'着'及相关的语法现象[On the locative preposition zhe and related grammatical phenomena]. Zhöngguó yŭwén yánjiü, 2, pp. 1-27.

ZHÀO Jĩnmíng 赵金铭 (1995). Xiàndài Hànyŭ bŭyǔ wèizhì shang de zai hé dao jíqí ruòhuà xíngshì de 现代汉语补语位置上的 '在” 和 '到” 及其弱化形式 '的' [Zai and dao in the complement position and their weak form de in contemporary Chinese]. Zhōngguó yŭyán Xuébào, 7, pp. 1-14.

ZHŌNGGUÓ SHÈHUİ KEXUÉYUÀN YǓYÁN YÁNJIOSSUǑ CÍDIǍN BIĀNJÍSHÌ 中国社会科学院语言研究所词典编辑室, eds. (1996). Xiàndài Hànyǔ cidiăn 现代汉语词典 [Dictionary of modern Chinese]. Beijing : Shāngwù Yìnshūguăn. 
Chirkova K. \& Lamarre C. / Cahiers de Linguistique-Asie Orientale 34(2005) 169-220

ZHŌU Libō 周立波 (1952). Bàofêng zhòuyŭ 暴风骤雨 [The tempest]. Beijing : Rénmín Wénxué Chūbănshè.

ZHOUU Yīmín 周一民 (2002). Xiàndài Béijīnghuà yánjiū 现代北京话研究 [Research in modern Beijing Mandarin]. Beijing : Běijīng Shīfan Dàxué Chübănshè.

ZHŪ Déxī 朱德熙 (1961). 说 “的” [On de]. Zhōngguó yǔwén, 12, pp. 115.

ZHŪ Déxī (1982). Yúfá jiăngyì 语法讲义 [Talks on grammar]. Beijing : Shāngwù Yìnshūguăn.

ZHŪ Déxī (1987). Xiàndài Hànyǔ yúfá yánjiū de duixiàng shi shénme? 现 代汉语语法研究的对象是什么? [What is the aim of modern Chinese grammar studies?]. Zhōngguó y̌̌wén, 5, pp. 321-329.

Christine LAMARRE

The University of Tokyo

Language and Information Sciences

3-8-1 Komaba, Meguro

TOKYO 153-8902

JAPAN

lamarre@boz.c.u-tokyo.ac.jp
Katia CHIRKOVA

Research School CNWS

Leiden University

Nonnensteeg 1-3

P.O. Box 9515

2300 RA LEIDEN

THE NETHERLANDS

k.chirkova@let.leidenuniv.nl 